\title{
House Prices, Heterogeneous Banks and Unconventional Monetary Policy Options
}

\author{
Andrew Lee Smith ${ }^{1}$ \\ First Draft: May 5, 2013 \\ This version: October 9, 2013
}

\begin{abstract}
Bank regulators acknowledge that large U.S. commercial banks allocate considerably more resources to originating and trading off-balance sheet assets than their smaller counter parts. In this paper: (i) I show the asset concentration in these large banks moves closely with home prices due to the collateralized nature of off-balance sheet assets. (ii) I then develop a general equilibrium capable of capturing this asset redistribution between heterogeneous banks. When home prices fall, endogenously tightening leverage constraints force the big productive banks to unload real-estate secured debt to small unproductive banks. The redistribution to less productive banks sets off an asset price spiral in the model - amplifying typical downturns into deep recessions. The model has predictions for the joint behavior of finance premiums, output, home prices and the share of assets held by large banks. (iii) I use a VAR to confirm the model's predictions for these variables are consistent with the data. (iv) Finally, I use this empirically verified model to examine the effectiveness of unconventional monetary policy in mitigating a recession generated by a drop in housing demand. Despite the fact that both equity injections into "Too Big to Fail" banks and asset purchases by the Fed such as "QE 1/2/3" mitigate the crisis, the nuances of the policies are important. A prolonged asset purchase program is preferable to a short-term equity injection.
\end{abstract}

Keywords: Financial Crises, Financial Frictions, Housing, Unconventional Monetary Policy JEL Codes: E32, E44, G01, G21

\footnotetext{
${ }^{1}$ asmith05@ku.edu PhD Candidate, University of Kansas, Department of Economics, 1460 Jayhawk Blvd. Lawrence, KS 66044. I would like to thank participants in the Macroeconomics Research Seminar at the University of Kansas for their comments and feedback. Additionally, thanks to participants at the 2013 Midwest Econometrics Group Meetings at Indiana University and the 2013 Missouri Valley Economics Association Conference for helpful questions. I would also like to thank Shu Wu and Joe Haslag for insightful conversations regarding this paper. Finally, I would like to thank my Dissertation Advisor, John Keating, for his support and encouragement.
} 


\section{Introduction}

The expansion leading up to and the subsequent Great Recession were intimately linked to the rise and collapse in housing prices. The exact linkages between housing and the macroeconomy are now being brought to light. This paper contributes to this important and growing literature by examining the behavior of the distribution of assets between large and small banks and home prices. Over the last decade as home prices increased, so too did the concentration of off-balance sheet assets in the largest U.S. commercial banks. When home prices later plunged, these assets were dispersed throughout the banking sector.

How is the timing of this redistribution linked to home prices? What are the implications for the business cycle? And importantly: How might the Fed use unconventional policy tools affect the economy when the distribution of assets between banks matters? In this paper I seek an answer to these questions. The results presented suggest this endogenous asset redistribution occurs due to the interacting bank/borrower financial frictions. An economic downturn in this financially fragile environment cause home prices, and the price of assets secured by housing, to spiral down resulting in a more severe recession. However the same mechanism that causes the asset redistribution and the resulting amplification provides an avenue for unconventional monetary policy. Equity injections into "Too Big to Fail" banks (such as the TARP) or "QE" policies (such as QE1 and QE3) can reduce the severity of the recession and speed-up the recovery.

\section{Detailed Roadmap}

The Data Section (2) analyzes how the concentration of off-balance sheet assets in large banks moves with home prices. I argue the timing of the asset redistribution and the collateralized nature of these assets suggest the assets shift from big banks to small banks when home prices drop due to changes in the underlying collateral values.

The Model With this hypothesis in mind, in Section (3) I develop a general equilibrium model with a heterogeneous banking sector. In the model, firms finance investment using a mix of collateralized loans secured by real-estate and unsecured loans which require a finance premium. Due to their productivity advantage, big banks place a greater value on secured assets than do small banks. Endogenously tightening leverage constraints force big banks to unload these assets to smaller banks when home prices fall, setting off an asset price spiral, which pushes borrowers into costly financing. Section (3.4) highlights the model's ability to generate larger and more persistent responses to macroeconomic shocks typically attributed with driving the business cycle. The model's predictions are then tested using impulse response functions from an estimated FS-VAR in Section (4). 
The Policy Implications In Section (5) I turn the focus to unconventional policy options of the sorts witnessed during the recent financial crisis. The controversial policies of injecting equity into large banks (deemed "Too Big to Fail") and large-scale asset purchases (LSAP, such as QE1 and QE3 where the Fed purchased mortgage backed securities) can be analyzed in this empirically validated model. Model simulations following a large contraction in housing demand show that equity injections and LSAP's are both effective in mitigating the asset redistribution which worsens the recession. Interestingly, in the model both policies come at zero long-run cost to tax payers and increase welfare, however the details of the policies are important. Short-term equity injections limit the worst of the crunch, however the recovery is still slow as equity is paid back before the economy recovers. Meanwhile, a persistent LSAP program can speed up the recovery and doesn't carry the political controversies associated with the government taking an ownership stake in a private financial institution.

\section{Bank Heterogeneity, Asset Concentration and Home Prices}

In this section I present evidence using the OCC's Quarterly Derivatives Report to document two important facts. First, large U.S. commercial banks differ from their counterparts in terms of the resources they allocate to trading complex financial instruments. Without this heterogeneity, the distribution of assets between large and smaller banks would be irrelevant for determining market outcomes. Second, during the run-up in housing prices off-balance sheet asset concentration in the largest U.S. commercial banks increased. Even with the heterogeneity identified in the first point, without asset redistribution there would be little concern of amplification.

I then provide an explanation as to why this redistribution occurs with movements in home prices. The timing of the redistribution aligns with the timing of the collapse of the Asset Backed Commercial Paper (ABCP) market, which Brunnermeier (2009) attributed to a drop in the value of mortgage backed securities (MBS). This suggest the same factor caused assets to shift from large banks to small banks. Indeed, there are several linkages between off-balance sheet assets and MBS's stemming from: credit default swaps, interactions with government sponsored enterprises such as Fannie Mae and Freddie Mac and the collateralized nature of interest-rate contracts.

\section{Measuring the Off-Balance Sheet Assets of Large Banks}

In what follows, I measure off-balance sheet assets using the total credit exposure measure from the Office of the Comptroller of the Currency's (OCC) Quarterly Derivatives Report 
Breuer (2000). These quarterly derivative's reports provide firm level data for the 25 largest U.S. commercial banks and aggregate data for all commercial banks. There are six institutions which are consistently near the top of this list providing a clear separation between big commercial banks and the rest of the industry. In particular, the banks I classify as large are:

1. JP Morgan Chase Bank NA

2. Citibank National Assn

3. Bank of America NA

4. HSBC Bank USA National Assn

5. Wachovia Bank National Assn

6. Wells Fargo Bank NA

One challenge to tracking these firms over time is dealing with mergers and acquisitions. I handle this by adding the off-balance sheet asset's of acquired banks to the acquiring bank's asset's to create (as much as is possible) a consistent time series ${ }^{2}$. Throughout this paper, the variable Large Bank Share refers to the share of total credit risk held by these six banks relative to all U.S. commercial banks.

\subsection{Bank Heterogeneity}

As of 2007:Q1 954 insured commercial banks reported derivatives activity (OCC, 19982012) . However, the 6 largest dealers held over $97 \%$ of all contracts at this time. While this was near a peak in market concentration, the average share held by the 6 largest banks from 1998:Q2 to 2012:Q4 is near 90\%. Although market concentration usually represents economic inefficiency and can pose systemic risk by allowing banks to become, "Too Big To Fail," the OCC refers to the derivatives market concentration as "appropriate" and hence not a concern :

...because the highly specialized business of structuring, trading, and managing the full array of risks in a portfolio of derivatives transactions requires sophisticated tools and expertise, derivatives activity is appropriately concentrated in those few institutions that have made the resource commitment to be able to operate the business in a safe and sound manner. Typically, only the largest institutions have the resources, both in personnel and technology, to support the requisite risk management infrastructure.

\footnotetext{
${ }^{2}$ For details regarding mergers and how I deal with the classification of investment banks as commercial banks following the financial crisis see Table 3 the appendix.
} 
This quote provides some narrative evidence of bank heterogeneity. Moreover, the notion that "Bigger is Better" is consistent with the recent empirical findings of Wheelock and Wilson (2012) and Bos and Kolari (2013) who find that when off-balance sheet activities are included, the banking industry is subject to increasing returns to scale. This finding is in stark contrast to productivity studies which focus on traditional bank activities - suggesting the increasing returns to scale is particularly a feature of off-balance sheet activities. It is not particularly surprising that big banks are more efficient at trading and broking off-balance sheet assets due to the complicated nature of this market. These large banks possess a level of expertise in dealing with derivatives that other banks simply do not have due to their size.

\subsection{Off-Balance Sheet Asset Redistribution Across the Housing Cycle}

Figure 1: Real home prices and the share of off-balance sheet assets held by large banks over the last decade. Real home prices are normalized to have a pre-recession peak of 100 .

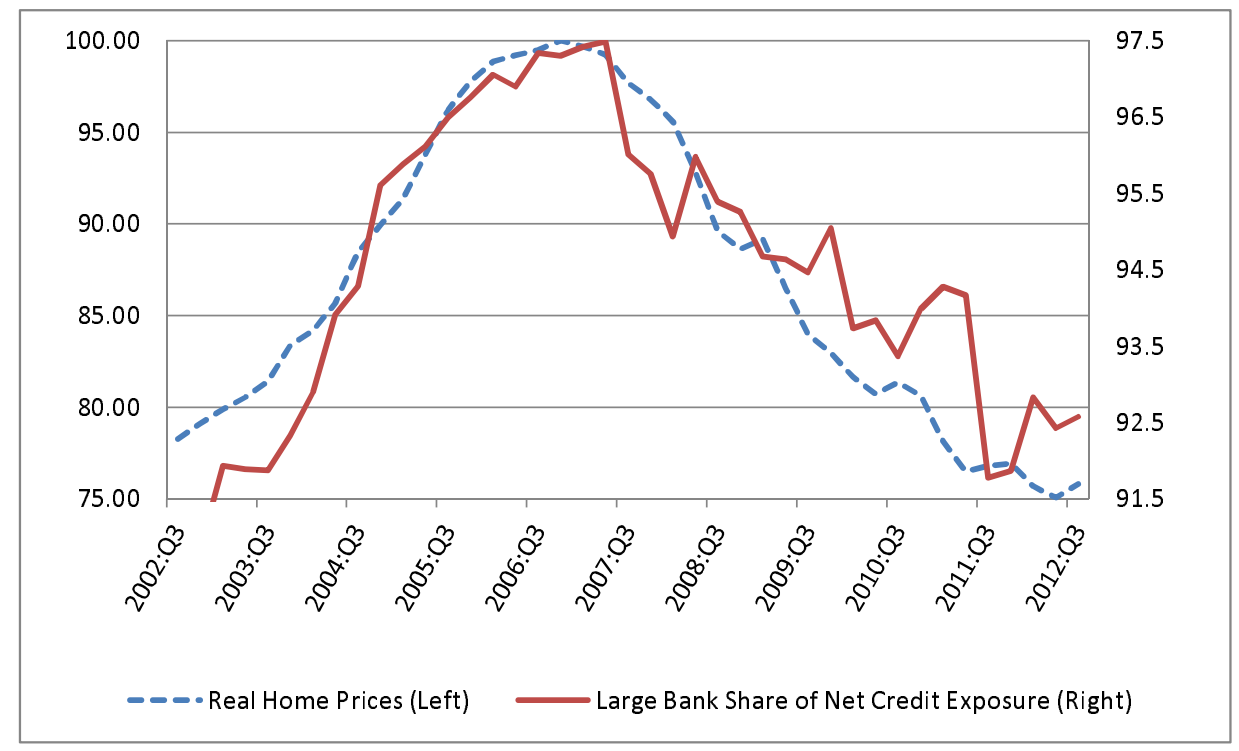

In Figure 1, I document a distributional effect during the housing cycle. As home prices gained positive momentum, off-balance sheet credit exposure became increasingly concentrated in large banks. Around 2007:Q3, as home prices plateaued the credit exposure reverted back to average levels.

Since total credit exposure takes into consideration market factors such as the maturity and liquidity of the contracts, it is theoretically possible for the share of credit exposure to 
vary with home prices without large banks actively adjusting their positions. For example, maybe large banks took on riskier, less liquid contracts relative to small banks. With this reasoning it is possible large banks were not actively adjusting their credit exposure, but instead there was a quality effect where by the value of large bank's assets fell while small banks assets increased in price. This leaves open the possibility that total credit exposure may be affected without any active adjustment of the bank's contract positions.

Although this can't be ruled out, the available evidence suggests this is unlikely. Adrian and Shin (2013) study the behavior of large commercial and investment banks over the last 15 years. They finds these firms actively adjust their leverage ratios across the business cycle.

"...intermediaries are shredding risk and withdrawing credit precisely when the financial system is under the most stress, thereby serving to amplify the downturn."

(a) Large Banks

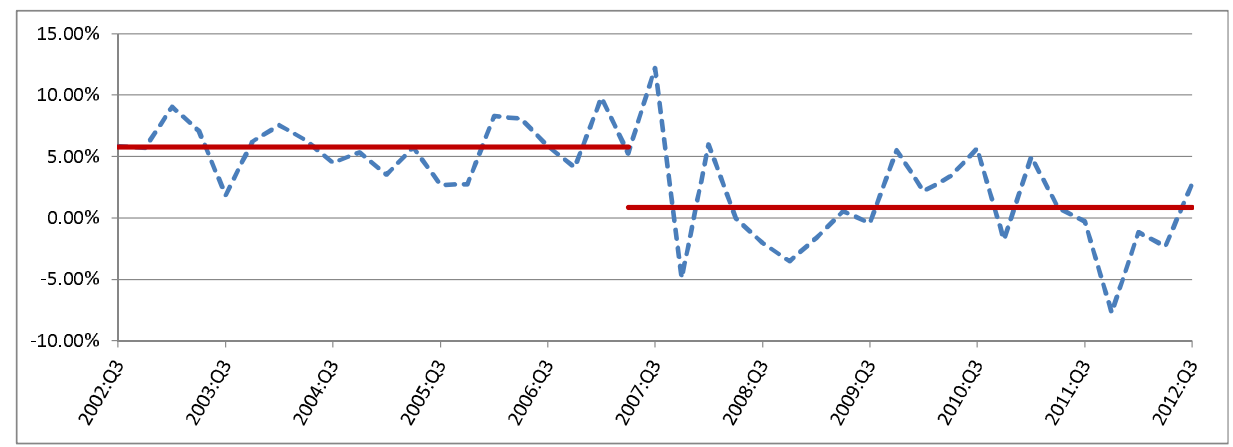

(b) Small Banks

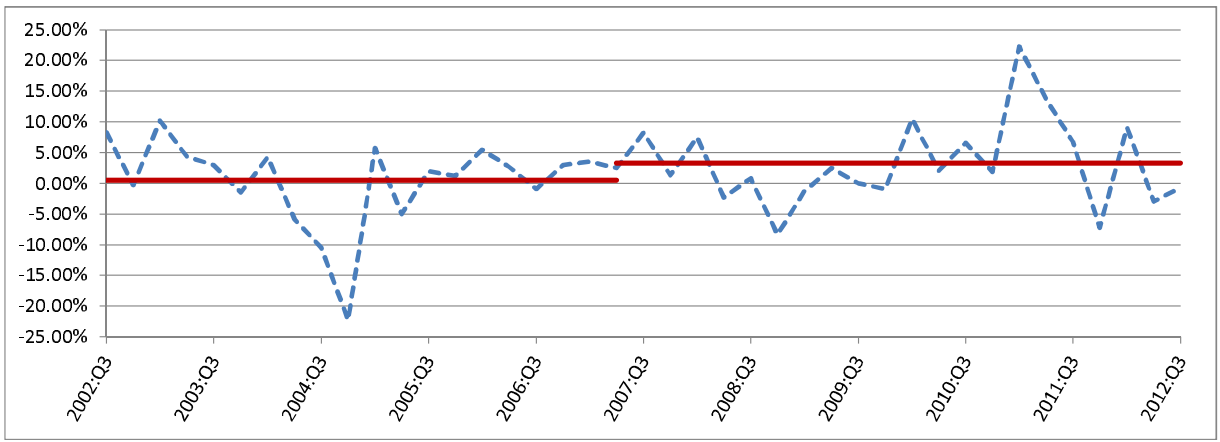

Figure 2: Growth rate of notional value of off-balance sheet assets. Red solid lines denote sample means. 
To examine how the timing of these adjustments aligns with home prices, I plot the growth rate of the large and small banks' balance sheet in notional values. Notional values do not give any sense of market prices. Consequently, movements in these values are not useful for assessing the market value of a bank's derivative positions at any given moment. None the less, if an institution wanted to adjust their credit exposure, all other things constant, they would be required to adjust their notional position over time. A consistently higher growth rate of notional values would suggest a bank is trying to increase its credit exposure. Meanwhile consistently lower growth rate of notional values would suggest a bank is attempting to reduce its credit exposure.

Figure 2 shows that large banks were aggressively increasing the notional size of their 'off-balance sheet' prior to the peak in home prices in early 2007. Meanwhile, after home prices plateaued, the size of large banks 'off-balance sheet' stagnated. The opposite pattern holds true for small banks. This suggest a change in the distribution of off-balance sheet assets took place whose timing matches the rise and fall of home prices.

\subsection{Off-Balance Sheet Asset Collateralization}

Here I show the asset redistribution documented in Figure 1 occurs at the same time assetbacked commercial paper (ABCP) markets deteriorated. This timing combined with the collateralized nature of off-balance sheet assets suggest the decrease in collateral value/quality that deteriorated the $\mathrm{ABCP}$ market also played a role in the redistribution from large banks to small banks.

Brunnermeier (2009) notes that as the financial crisis unfolded assets that were collateralized were impacted differently than assets that were not collateralized. I reproduce below a graphic outlining the behavior of $\mathrm{ABCP}$ and unsecured commercial paper (UCP) during the crisis.

Figure 3 highlights the divergent behavior between ABCP and UCP. As Brunnermeier (2009) points out, the timing of the fall in ABCP, which coincides with the fall in home prices, suggests troubles in the ABCP market were driven by the assets which severed as collateral such as MBS's. Although UCP also experiences a peak and then fall, the timing suggests problems in the UCP were driven by spillovers from the housing market into the broader economy. Interestingly, comparing Figures 1 and 3, the asset redistribution highlighted in Section 2.2 took place the same time the ABCP began to collapse.

How are off-balance sheet assets linked to Mortgage Backed Securities?

1. One link between off-balance sheet assets and MBS are Credit Default Swaps (CDS), the very assets which essentially insured MBS's. Although CDS's were the fastest 
Figure 3: Real home prices and Commercial Paper. All series are normalized to have a pre-recession peak of 100

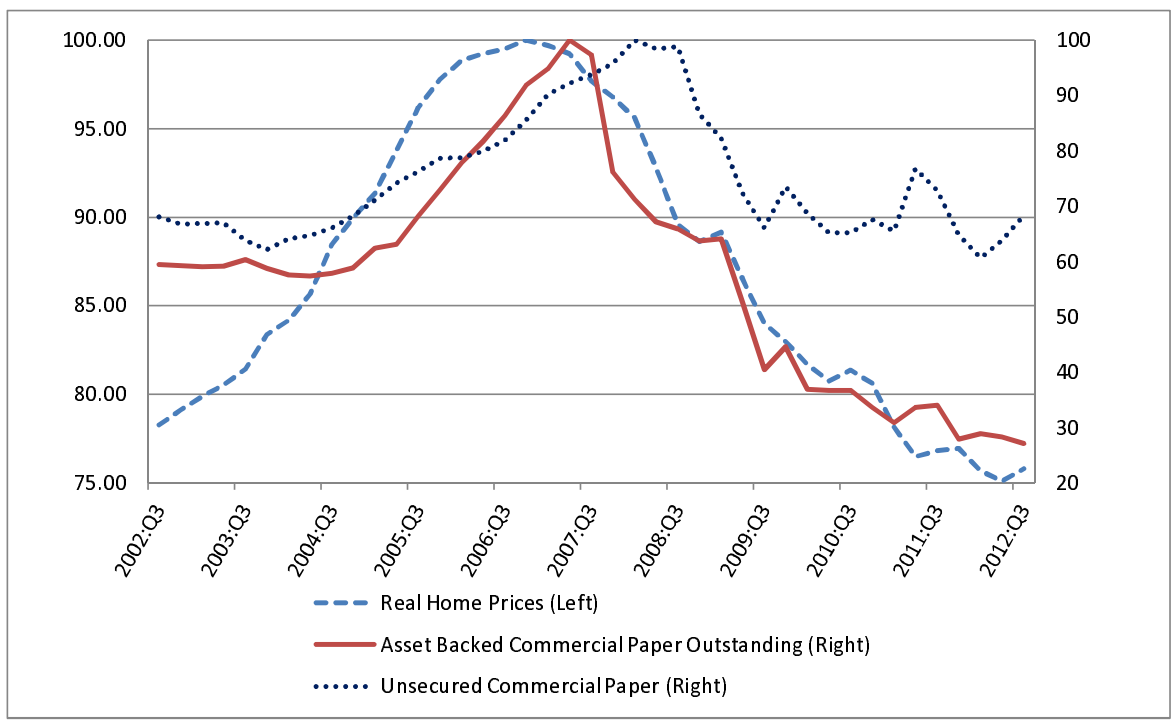

growing credit derivative at the time of the crises, it made up a relatively small portion of commercial banks off-balance sheet assets (OCC, 1998-2012). This suggests interest rate and equity contracts, two assets which comprise the majority of the notional value of derivatives contracts held by commercial banks, are also linked to MBS's.

2. A second channel that links MBS's to off balance sheet assets is through interest rate and equity contracts with Government Sponsored Enterprises (GSEs). It is common for GSE's such as Fannie Mae and Freddie Mac to use interest-rate swaps to fund MBS creation (Parkinson, Gibson, Mosser, Walter, and LaTorre, 2005). These contracts offer a source of financing that hedges their income stream. Fixed rate loan payments are offset with fixed rate debt via interest rate swaps. Moreover, large banks have an incentive to hedge these positions with equity swaps in the same firms. For example, if they were to lose on the interest-rate swap, they would cover themselves by taking the opposite position in an equity swap.

3. The collateraliztion of derivatives further links off-balance sheet assets to MBS's. Large credit exposures from derivatives are typically collateralized (OCC, 1998-2012). According to the International Capital Market Association, prior to the financial crisis interest-rate contracts were often collateralized by MBSs (ICMA, 2013). Consequently, interest-rate contracts that were not directly used to finance MBS creation experienced exposure to MBSs via collateralization. 


\section{A DSGE Model of the Housing-Cycle Amplification effect from Off-Balance Sheet Asset Reallocation}

In this section I develop a general equilibrium model capable of capturing the asset redistribution between big and small banks that occurs when home prices change. The model implies that bank heterogeneity amplifies typical business cycles when large banks are leverage constrained. To the extent these large financial firms can more efficiently intermediate secured-debt, the asset concentration that occurs during an upswing moves the economy closer to a Pareto outcome. The other side of this coin however implies that slumps can be made more severe due to this redistribution.

\subsection{Related Models and How this Model Differs}

The notion that heterogeneity between agents can lead to amplification effects is not new. Kiyotaki and Moore (1997) (hereafter KM) show that an asset price spiral may occur if productive agents are borrowing constrained and the tightness of this constraint depends on asset prices. If an adverse shock results in decreased output for the productive agent, they have fewer assets to borrow against which results in unproductive agents absorbing these assets, which they are willing to do so only at reduced prices. However, since the productive agents binding constraint depends on the price of the asset, the decrease in price only further tightens the collateral constraint - starting the process over.

The model I present here builds on the keen insight of this amplification effect, however the KM model is silent with regards to default rates since agents in the model never default. This aspect was critical during the recent crisis where home prices and MBS fell in value in large part due to rising defaults on risky sub-prime loans. However, Bernanke, Gertler, and Gilchrist (1999) (hereafter BGG) develop a financial friction where risky projects are financed and each period some share of financed projects will fail resulting in no repayment and hence default. However, BGG features no illiquid collateral, instead all assets are already monetary. This feature of the model misses the role of market liquidity (or illiquidity) which is elegantly captured by KM.

Moreover, BGG and KM don't explicitly include banks. ${ }^{3}$ To the extent that deposits and bank capital are perfect substitutes, the financial sector can be left in the background as household's can then directly fund projects with deposits. On the other hand, if bank

\footnotetext{
${ }^{3}$ In KM the agents can simply be re-interpreted as banks with investment opportunities and this would capture supply side financial frictions. However, to the extent that there are also demand side financial frictions this single banker/investor model would understate the role of collateral values in mitigating this friction.
} 
capital serves a special role in mitigating financial frictions faced by the bank (on the supply side), then these agents must be explicitly modeled.

Gertler and Kiyotaki (2010) present a model with financial intermediaries where bank capital facilitates bank's ability to obtain funds. Banks in their model face frictions in raising loanable funds however, there are no demand side frictions, so that all loans face zero default risk. Additionally, there is no clear distinction between big banks and small banks. Banks in their model differ in terms of their investment opportunities but not their efficiency in intermediating loans. Therefore, building on Hafstead and Smith (2012), I include heterogeneous banks with market power - creating bank capital in the model. Banks in this environment differ in size due to differences with regards to their efficiency. Along this dimension, my work resembles Adrian and Shin (2010) who model supply side financial heterogeneity in terms of financial firms ability to value assets.

Finally, in contrasts to these previous contributions, I follow Iacoviello (2005) and Iacoviello and Neri (2010) who explicitly model a housing market. In particular, I do not interpret asset prices generally, but instead I model assets whose underlying value as collateral is tied to home prices. Although my inclusion of demand side and supply side financial frictions in terms of large productive banks and small unproductive banks is novel, this is one of the clearest contributions of this paper. By focusing exclusively on assets whose values are tied to house prices, I am able to generate financial market deterioration from changes in primitives such as technology and preferences.

\subsection{Model Description}

The model consists of a household, a housing producer, a continuum of entrepreneurs who produce the final consumption good, a banking sector with 2 types of banks (productive and unproductive), both of whom finance investment for goods producers and lastly a central bank is modeled. In this section I will describe the behavior of each agent in turn. Many of the details including the full set of model equations are in the appendix as to not distract from the basic mechanism at work in the model. I follow the convention throughout the model that lower case variables are nominal and uppercase variables are in real terms including interest rates.

\subsubsection{Household}

The household earns wages by renting labor to goods producers $L_{t}$ and home builders $L_{t}^{H}$. Additionally, they earn non-labor income from banks in the form of dividends $p_{t}$ Div $v_{t}$, transfer payments $p_{t}$ Trans $_{t}$ and principal plus interest payments $p_{t-1} D_{t-1} r_{t-1}^{D}$ on last periods deposits. The monetary authority may transfer any revenue back to the household in lumpsum form via $p_{t} T_{t}$. This income can be saved in the form of bank deposits $p_{t} D_{t}$ or spent on 
consumption $p_{t} C_{t}$ and housing $p_{t}^{H} H_{t}$. Also, any non-depreciated housing stock, $(1-\delta) H_{t-1}$, can be resold at the market price $p_{t}^{H}$. The resulting budget constraint in any period $t=$ $0,1,2, \ldots$ is given by,

$p_{t} C_{t}+p_{t}^{H}\left[H_{t}-\left(1-\delta^{H}\right) H_{t-1}\right]+p_{t} D_{t} \leq w_{t} L_{t}+w_{t}^{H} L_{t}^{H}+p_{t-1} D_{t-1} r_{t}^{D}+p_{t}$ Div $+p_{t} \operatorname{Trans}_{t}+p_{t} T_{t}$.

Although I follow Iacoviello (2005) and Iacoviello and Neri (2010) by modeling a housing market, I do not include home equity borrowing constraints on the household side. Where they focus on the wealth effects of housing price changes in terms of financing consumption, I focus more so on real-estate as collateral for investment and the interaction of house prices and off-balance sheet asset prices. That being said, in general equilibrium changes in home prices can impact consumption via traditional income and substitution effects, but not through the home equity channel highlighted by Iacoviello (2005).

The household maximizes their lifetime expected utility subject to the flow budget constraint above. The household's lifetime expected utility is specified by

$$
U=\sum_{i=0}^{\infty} \mathbb{E}_{t}\left\{\ln \left(C_{t+i}\right)+\eta_{t+i}^{H} \ln \left(H_{t+i}\right)+\eta^{L} \ln \left(1-L_{t+i}\right)+\eta^{L^{H}} \ln \left(1-L_{t+i}^{H}\right)\right\},
$$

where $\eta_{t}^{H}$ represents a shift in the elasticity of demand for housing. I specify this as an exogenous process following a first order auto-regressive process, in line with Iacoviello and Neri (2010).

$$
\ln \left(\eta_{t}^{H}\right)=\left(1-\rho_{\eta^{H}}\right) \bar{\eta}^{H}+\rho_{\eta^{H}} \ln \left(\eta_{t-1}^{H}\right)+\varepsilon_{t}^{\eta^{H}} \quad \varepsilon_{t}^{\eta^{H}} \sim \mathcal{N}\left(0, \sigma_{\eta^{H}}\right)
$$

\subsubsection{Goods Production}

The goods producing sector is comprised of a continuum of entrepreneurs. Entrepreneurs have limited resources to finance capital required to produce the final good so they must borrow from banks. A financial friction arises whereby entrepreneurs borrow funds from banks this period to purchase capital used in production next period. Their output next period is subject to idiosyncratic productivity disturbances only observable by banks after paying a monitoring cost.

\section{Entrepreneur's Debt Contract: The Demand Side Financial Friction}

A continuum of entrepreneurs $j \in \mathbb{R}_{+}$supply wholesale goods to retailers using capital and labor. Entrepreneurs only live for 2 periods and only care about their second period 
utility. In the first period they have no endowment and no technology but they have a unit of labor supply. In the second period of their lives they are endowed with 1 unit of an asset which can be narrowly thought of as land, $\bar{N}$, which can be transformed into housing only by entrepreneurs and banks. However, capital must be purchased this period to be useful tomorrow. Denote the quantity of capital purchased in period $t$ by entrepreneur $j$ by $K_{t}^{j}$ and denote the period $t$ price of capital by $q_{t}$. To purchase this capital the entrepreneur will receive financing from the banking sector. More specifically, the entrepreneur uses last period's wages $p_{t} W_{t}^{E}$ and pledges tomorrows endowment $\bar{N}^{j}$ as collateral for a secured loan in the amount $p_{t}^{N} \bar{N}^{j}$ and the remaining portion of the capital purchase is financed with an unsecured loan in the amount $p_{t} B_{t}^{j}$. More concretely,

$$
q_{t} K_{t}^{j}=p_{t}^{N} \bar{N}^{j}+p_{t} B_{t}^{j}+p_{t} W_{t}^{E}
$$

is entrepreneur $j^{\prime} s$ budget constraint.

Without default, distinguishing between secured and unsecured loans is trivial. However, in the second period of their life, entrepreneurs are subjected to an idiosyncratic productivity shock $\omega_{t+1}^{j}$ which is i.i.d. across home builders and time. I assume throughout the analysis in this paper, $\omega_{t+1}^{j} \sim \ln \mathcal{N}\left(\frac{-\left(\sigma_{t}^{\omega}\right)^{2}}{2}, \sigma_{t}^{\omega}\right)$ with CDF at time $t$ denoted by $F_{t}\left(\omega_{t+1}^{j}\right)$. The choice of parameters implies $\mathbb{E}\left\{\omega_{t+1}^{j}\right\}=1$ so that in the aggregate this idiosyncratic shock has no direct impact on production, but the existence of uncertainty at the firm level impacts aggregate output through financial imperfections (BGG). To capture exogenous increases in the cross-sectional dispersion of idiosyncratic productivity shocks I allow $\sigma_{t}^{\omega}$ to vary over time. I posit the simple auto-regressive process,

$$
\ln \left(\sigma_{t}^{\omega}\right)=\left(1-\rho_{\sigma^{\omega}}\right) \overline{\sigma^{\omega}}+\rho_{\sigma^{\omega}} \ln \left(\sigma_{t-1}^{\omega}\right)+\varepsilon_{t}^{\sigma^{\omega}} \quad \varepsilon_{t}^{\sigma^{\omega}} \sim \mathcal{N}\left(0, \sigma_{\sigma^{\omega}}\right)
$$

for this demand-side risk shock. Christiano, Motto, and Rostagno (2013) show that such shocks have played a significant role in shaping the U.S. business cycle. Moreover, these shocks prove useful in the empirical analysis of the paper as they provide a structural interpretation for exogenous increase in the external finance premium.

Since projects are financed before the idiosyncratic productivity shock can be observed by either the entrepreneur or the bank, entrepreneurs who receive a low productivity value will default upon their loan. Denote the real gross interest rate on unsecured loans by $R_{t}^{L, j}$ and denote the gross real return on capital common to all entrepreneurs by $R_{t+1}^{K}$. Then for any entrepreneur $j$, we can define the cut-off value of $\bar{\omega}_{t+1}^{j}$ by the equation

$$
\bar{\omega}_{t+1}^{j} R_{t+1}^{K} K_{t}^{j} q_{t}=p_{t} B_{t}^{j} R_{t}^{L, j} .
$$


This equation defines the minimum level of productivity needed to pay back the unsecured loan. For entrepreneur $j$, the loan will be repaid if $\omega_{t+1}^{j} \geq \bar{\omega}_{t+1}^{j}$ and will otherwise be defaulted upon. However, the bank can not observe the level of productivity without paying an auditing cost in proportion $\mu \in(0,1)$ to the entrepreneur's revenue. ${ }^{4}$ Banks who do not pay for auditing never find out if the entrepreneur actually received a low productivity draw or if they simply chose to renege on their loan. Given this arrangement, the optimal debtcontract dictates that banks will audit only defaulting home builders and only entrepreneurs who receive a bad-draw will default on their loans.

To make matters more explicit I define the expected revenue to the bank for loaning $p_{t} B_{t}^{j}$ to entrepreneur $j$ in (5). This expected revenue is comprised of 2 terms, the first of which is non-defaulting loan revenue and the second is revenue net of auditing costs on non-performing loans.

$$
\underbrace{\left(1-F_{t}\left(\bar{\omega}_{t+1}^{j}\right)\right) p_{t} B_{t}^{j} R_{t}^{L}}_{\text {Non-Defaulting Payoff }}+\underbrace{(1-\mu) \int_{0}^{\bar{\omega}_{t+1}^{j}} \omega_{t+1}^{j} d F_{t}\left(\omega_{t+1}^{j}\right) R_{t+1}^{K} K_{t}^{j} q_{t}}_{\text {Defaulting Payoff }}
$$

For the bank to be willing to make this loan, this expected pay-off must be at least equal to bank's cost of making the loan. In BGG the cost of making the loan is simply the cost of obtaining the funds via deposits $-p_{t} B_{t}^{j} R_{t}^{D}$. However since the banking sector in this model has market power this is no longer the case. For the time being simply define the real cost per dollar loaned by $R_{t}^{E}$. Then the incentive compatibility constraint can be expressed as,

$$
p_{t} B_{t}^{j} R_{t}^{E}=\left(1-F_{t}\left(\bar{\omega}_{t+1}^{j}\right)\right) p_{t} B_{t}^{j} R_{t}^{L}+(1-\mu) \int_{0}^{\bar{\omega}_{t+1}^{j}} \omega_{t+1}^{j} d F_{t}\left(\omega_{t+1}^{j}\right) R_{t+1}^{K} K_{t}^{j} q_{t} .
$$

We can simplify this expression (and the resulting entrepreneur's optimization problem) by defining the following terms. First let $G_{t}\left(\bar{\omega}_{t+1}^{j}\right)$ be defined as the expected productivity value for defaulting entrepreneurs.

$$
G_{t}\left(\bar{\omega}_{t+1}^{j}\right)=\int_{0}^{\bar{\omega}_{t+1}^{j}} \omega_{t+1}^{j} d F_{t}\left(\omega_{t+1}^{j}\right)
$$

Also let $\Gamma_{t}\left(\bar{\omega}_{t+1}^{j}\right)$ be defined as the expected share of entrepreneurial profits going to the bank gross of auditing costs.

$$
\Gamma_{t}\left(\bar{\omega}_{t+1}^{j}\right)=\left(1-F_{t}\left(\bar{\omega}_{t+1}^{j}\right)\right) \bar{\omega}_{t+1}^{j}+G_{t}\left(\bar{\omega}_{t+1}^{j}\right)
$$

\footnotetext{
${ }^{4}$ This follows from Townsend (1979), but has been popularized in this context by Carlstrom and Fuerst (1997) and BGG.

${ }^{5} R_{t}^{E}$ is explicitly defined in the description of the banking sector in the appendix using the approach laid out in Hafstead and Smith (2012)
} 
Now I can combine (6) with (4), (7) and (8) to rewrite the bank's incentive compatibility as,

$$
p_{t} B_{t}^{j} R_{t}^{E}=\left(\Gamma_{t}\left(\bar{\omega}_{t+1}^{j}\right)-\mu G_{t}\left(\bar{\omega}_{t+1}^{j}\right)\right) R_{t+1}^{K} K_{t}^{j} q_{t} .
$$

We can now formally state the problem faced by entrepreneur $j$. To keep the debt-contract tractable, I assume the entrepreneur is risk-neutral with regards to aggregate consumption. In particular, I assume they seek to maximize their income and then allocate that income between consumption and housing services. Entrepreneur $j$ therefore seeks to maximize total income ${ }^{6}$ subject to the bank's IC constraint.

$$
\begin{array}{ll}
\max _{K_{t}^{j}, \bar{\omega}_{t+1}^{j}} & \left(1-\Gamma_{t}\left(\bar{\omega}_{t+1}^{j}\right)\right) R_{t+1}^{K} K_{t}^{j} q_{t} \\
\text { subject to } & {\left[q_{t} K_{t}^{j}-p_{t}^{N} \bar{N}^{j}-p_{t} W_{t}^{E}\right] R_{t}^{E}=\left(\Gamma_{t}\left(\bar{\omega}_{t+1}^{j}\right)-\mu G_{t}\left(\bar{\omega}_{t+1}^{j}\right)\right) R_{t+1}^{K} K_{t}^{j} q_{t}}
\end{array}
$$

The solution to this optimization problem pins down the cut-off value $\bar{\omega}_{t+1}^{j}$ and the entrepreneur's demand for capital $K_{t}^{j} \cdot{ }^{7}$ The problem is identical in nature to the problem entrepreneurs face in BGG who show the optimal debt contract has the property that the default rate and external finance premium move inversely with net-worth. In this model, the net-worth component is replaced with the collateral value, implying that $\partial \bar{\omega}_{t+1}^{j} / \partial p_{t}^{N}<0$ finance premiums and default rates will move in the opposite direction of collateral prices.

\section{Aggregate Goods Production}

The previous section describes the firm-level behavior in the goods producing sector, specifically it describes the debt-contract problem faced by each producer. In this section, I describes the industry wide behavior. Each entrepreneur (in the second period of their life) has access to the production technology, $Y_{t}^{j}=\omega_{t}^{j}\left(K_{t-1}^{j}\right)^{\alpha_{G}}\left(L_{t}^{G, j}\right)^{1-\alpha_{G}}$, which can be aggregated over due to constant returns to scale. The aggregate goods production technology in any given period $t$ is specified as

$$
Y_{t}=Z_{t}^{G}\left(K_{t-1}\right)^{\alpha_{G}}\left(L_{t}^{G}\right)^{1-\alpha_{G}}
$$

where $Z_{t}^{G}$ is an exogenous technology process which affects all entrepreneurs equally. I assume this technology follows a first-order autoregressive process.

$$
\ln \left(Z_{t}^{G}\right)=\left(1-\rho_{Z^{G}}\right) \overline{Z^{G}}+\rho_{Z^{G}} \ln \left(Z_{t-1}^{G}\right)+\varepsilon_{t}^{Z^{G}} \quad \varepsilon_{t}^{Z^{G}} \sim \mathcal{N}\left(0, \sigma_{Z^{G}}\right)
$$

\footnotetext{
${ }^{6}$ Notice the entrepreneur's income can be re-written as $\int_{\bar{\omega}_{t+1}^{j}}^{\infty} \omega_{t+1}^{j} d F\left(\omega_{t+1}^{j}\right) R_{t+1}^{K} K_{t}^{j} q_{t} \quad$ $\left(1-F_{t}\left(\bar{\omega}_{t+1}^{j}\right)\right) R_{t}^{L} B_{t}^{j}=\left(1-\Gamma_{t}\left(\bar{\omega}_{t+1}^{j}\right)\right) R_{t+1}^{K} K_{t}^{j} q_{t}$ where I use (4) and (8).

${ }^{7}$ The first order conditions for this problem are in the appendix.
} 
The gross aggregate real return on holding a unit of capital from period $t-1$ to period $t$ is defined by

$$
R_{t}^{K}=\frac{\alpha_{G} \frac{Y_{t}}{K_{t-1}}+\left(1-\delta^{K}\right) Q_{t}}{Q_{t-1}}
$$

where I utilize the aggregate marginal product of capital from the Cobb-Douglas specification above $-M P_{K}=\alpha_{G} \frac{Y_{t}}{K_{t-1}}$.

The labor aggregate in the production function is a composite of labor supplied by the household, $L_{t}$, and labor supplied by this periods young entrepreneurs, $L_{t}^{E}$,

$$
L_{t}^{G}=\left(L_{t}^{E}\right)^{\alpha_{E}}\left(L_{t}\right)^{1-\alpha_{E}}
$$

This implies the wage paid to the household's labor and the wage paid to entrepreneurial labor are given by,

$$
\begin{aligned}
W_{t} & =\left(1-\alpha_{G}\right)\left(1-\alpha_{E}\right) \frac{Y_{t}}{L_{t}} \\
W_{t}^{E} & =\left(1-\alpha_{G}\right) \alpha_{E} \frac{Y_{t}}{L_{t}^{E}}
\end{aligned}
$$

I calibrate $\alpha_{E}=.01$ so that in equilibrium the household receives the majority of wages and variations in collateral values are the primary sources of movement in entrepreneur's balance sheets. The aggregate income of entrepreneurs in period $t$ is $\left(1-\Gamma_{t-1}\left(\bar{\omega}_{t}\right)\right) R_{t}^{K} K_{t-1} q_{t-1}$. I assume entrepreneurs, like the household, receive utility from consuming both the consumption good and housing services. Unlike households, entrepreneurs have the ability to transform their endowment of 'land' - $\bar{N}^{j}$ - into non-tradeable housing. Recall however, this endowment was leveraged last period to secure a loan in the amount $p_{t-1}^{N} \bar{N}^{j}$. Hence, entrepreneurs who are able, choose to payback the secured loan with interest $p_{t-1}^{N} \bar{N}^{j} r_{t-1}^{D}$ and then convert $\bar{N}^{j}$ into housing services one for one. If they don't payback the secured loan then they default on this contract and the bank takes possession of the collateral $\bar{N}^{j}$.

I assume in the aggregate, all the entrepreneurs who did not default on their unsecured loan, payback their secured loan and use the rest of their income on the consumption good. Those who defaulted on the unsecured loan have lost all income and hence do not consume anything. More specifically, the aggregate real consumption of entrepreneurs is given by

$$
C_{t}^{E}=\left(1-\Gamma_{t-1}\left(\bar{\omega}_{t}\right)\right) R_{t}^{K} K_{t-1} Q_{t-1}-\left(1-F_{t-1}\left(\bar{\omega}_{t}\right)\right) P_{t-1}^{N} \bar{N}^{j} R_{t-1}^{D} .
$$

"What micro-level preferences would give rise to this aggregate consumption behavior?" is an interesting question. In the appendix I describe one possible micro-structure that would 
lead to this aggregate consumption behavior. An appealing aspect of this description is the existence of a single default rate in the economy. ${ }^{8}$

\subsubsection{New Housing Production}

I assume new housing is produced in a purely competitive market and free from financial frictions. In particular, housing producers combine labor $L_{t}^{H}$ with housing specific technology, $Z_{t}^{H}$ in the production technology,

$$
H_{t}^{N e w}=Z_{t}^{H}\left(L_{t}^{H}\right)^{1-\alpha_{H}}
$$

where

$$
\ln \left(Z_{t}^{H}\right)=\left(1-\rho_{Z^{H}}\right) \overline{Z^{H}}+\rho_{Z^{H}} \ln \left(Z_{t-1}^{H}\right)+\varepsilon_{t}^{Z^{H}} \quad \varepsilon_{t}^{Z^{H}} \sim \mathcal{N}\left(0, \sigma_{Z^{H}}\right) .
$$

I model housing specific technology independent of technology in the goods producing sector since much of the economics growth over the last two decades has been IT-driven and housing production is a non IT-intensive industry. Moreover, this specification allows for goods technology process, $Z_{t}^{G}$, to play a significant role in determining output without implying a counterfactual negative correlation between home prices and GDP (see for example Davis and Heathcote (2005)). The resulting demand for labor from the housing sector takes the form

$$
W_{t}^{H}=\left(1-\alpha_{H}\right) P_{t}^{H} \frac{H_{t}^{N e w}}{L_{t}^{H}} .
$$

\subsubsection{Banking Sector: The Supply Side Financial Friction}

There are a unit measure of banks in the model each belonging to one of two types. I distinguish bank types by a superscript "P" for productive banks and a superscript "U" for unproductive banks (who make up $\nu$ share of the population). Productive banks represent the Large commercial banks in the data. These banks are more productive with repossessed collateral pledged by entrepreneurs to secure loans and hence value these 'Off-balance sheet' assets more than their unproductive counterparts. However, this efficiency creates a moral hazard problem for borrowers due to the possibility of productive banks wrongfully repossessing collateral and absconding with the profits. If this occurs, the entrepreneur's only recourse is to take the productive banks accumulated capital. To this extent, bankcapital mitigates the moral hazard concerns and allows the productive banks to hold more of these collateralized assets. An amplification effect emerges from the endogenous tightening and loosening of this moral hazard constraint which forces productive banks to adjust their holding of collateralized assets in response to movements in home prices.

\footnotetext{
${ }^{8}$ That is to say, the default rate on unsecured loans is the same as the default rate on secured loans. I choose this as a starting point although this assumption can be relaxed.
} 
For ease of exposition I describe factors common to both types of bank before describing each type's optimizing behavior. In particular, all banks have some degree of market power, face a balance sheet constraint and remit a fraction of profits each period back to the household in the form of dividends and various transfers. In what follows I generically refer to bank $i$ to reference one of the infinitely many identical banks within either type.

Each bank possesses a degree of market power which is captured by assuming a DixitStiglitz type aggregator function. As Hafstead and Smith (2012) point out, this has the simplifying feature that all banks serve all entrepreneurs and therefore face the same ex-ante and ex-post default rates. More specifically, aggregate loans are a CES index

$$
B_{t}=\left(\int_{0}^{1} B_{t}(i)^{\frac{\theta_{B}-1}{\theta_{B}}}\right)^{\frac{\theta_{B}}{\theta_{B}-1}}
$$

where $\theta_{B}$ is the elasticity of substitution between different bank loans and is calibrated to match aggregate lending rates. The corresponding price index which is dual ${ }^{9}$ to this quantity index is given by

$$
r_{t}^{B}=\left(\int_{0}^{1} r_{t}^{B}(i)^{1-\theta_{B}}\right)^{\frac{1}{1-\theta_{B}}} .
$$

This specification of the aggregate indexes implies each bank $i$ of type $T \in\{P, U\}$ faces the downward sloping demand for loans,

$$
B_{t}^{T}(i)=\left(\frac{r_{t}^{B, T}(i)}{r_{t}^{B}}\right)^{-\theta_{B}} B_{t} .
$$

Each bank $i$ must not only satisfy their demand for loans, but they must also abide to the balance sheet constraint,

$$
p_{t} B_{t}^{T}(i)+p_{t}^{N} N_{t}^{T}(i)=p_{t} D_{t}^{T}(i)+p_{t-1} B K_{t-1}^{T}(i)
$$

which simply states that assets (bank loans) must equal liabilities (bank deposits) plus bank capital, respectively.

Since banks use share holder's retained earnings to fund risky loans, I assume shareholders (households) require compensation. More specifically, each period the bank is allowed (by the central bank) to expose a fraction $\psi_{t}$ of bank capital to cover expected losses on unsecured

\footnotetext{
${ }^{9}$ Duality here refers to the price and quantity indexes which satisfy Fisher's factor reversal test, $\int_{0}^{1} r_{t}^{B}(i) B_{t}(i) d i=r_{t}^{B} B_{t}$.
} 
defaulted loans. Each period $t$, the fraction of loans that actually default is given by $F_{t-1}\left(\bar{\omega}_{t}\right)$. Hence, each period the bank transfers the nominal payment

$$
p_{t} \operatorname{Trans}_{t}^{T}(i)=F_{t-1}\left(\bar{\omega}_{t}\right) p_{t-1} \psi_{t-1} B K_{t-1}^{T}(i)
$$

to shareholders in order to compensate them for the capital that was exposed to covering losses on loans originated in period $t-1$. In this sense, the transfer to shareholders occurs only on realized, or ex-post, loan losses. Combining this transfer payment with dividend payments, bank capital evolves according to the following law of motion.

$$
p_{t} B K_{t}^{T}(i)=\gamma_{t}^{T} p_{t} \Pi_{t}^{T}(i)-p_{t} \operatorname{Trans}_{t}^{T}(i)+\left(1-\delta^{B K}\right) p_{t-1} B K_{t-1}^{T}(i)
$$

To summarize this, banks of type $T$ pay out a time varying fraction $\gamma_{t}^{T}$ of period $t$ profits as dividends and invest the remaining fraction in bank capital. Additionally, banks compensate shareholders for exposing retained earnings to potential losses via $p_{t} \operatorname{Trans}_{t}^{T}$ and lose a fraction of bank capital to depreciation. Following Gerali, Neri, Sessa, and Signoretti (2010), I assume bank investment decisions are made independently from bank profit maximization, however, I assume this fraction is time varying. In particular, I assume that $\gamma_{t}^{T}=\frac{\bar{\gamma}^{T}}{p_{t} \Pi_{t}^{T}}$ so that each period a constant amount of new equity is injected into the banks from shareholders. This implies realistically that banks respond to falling profits by paying out a smaller share of profits in dividends. Before proceeding to a specific description of each type of bank's problem, it useful to summarize these transfers by defining net investment in the banking sector.

$$
I_{t}^{B K}=\sum_{T \in\{P, U\}} s_{T}\left(\gamma_{t}^{T} p_{t} \Pi_{t}^{T}-p_{t} \operatorname{Trans}_{t}^{T}\right) \quad \text { where } s_{T}= \begin{cases}\nu & \text { if } T=U \\ 1-\nu & \text { if } T=P\end{cases}
$$

\section{Productive Bank}

The productive bank enters each period $t$ with inflows consisting of maturing unsecured loans $r_{t-1}^{B, P}(i) p_{t} B_{t-1}^{P}(i)$ and maturing secured loans $p_{t-1}^{N} N_{t-1}^{P} r_{t-1}^{D}$, of which, $\left(1-F_{t-1}\left(\bar{\omega}_{t}\right)\right)$ will be repaid in full. Denote the real income of all borrowers who are unable to repay last

periods loan by $\Phi_{t-1}\left(\bar{\omega}_{t}\right)$. The productive bank will receives the fraction $\frac{B_{t-1}^{P}(i)}{B_{t-1}}$ of $\phi_{t-1}\left(\bar{\omega}_{t}\right)$ net of auditing costs $\mu$ for the unsecured loan defaults. Additionally, the productive bank repossesses $F_{t-1}\left(\bar{\omega}_{t}\right) N_{t-1}^{P}(i)$, which is the collateral posted on the secured loans who defaulted. This repossessed collateral is transformed in to housing using the technology common to all banks, $H_{t}^{R}(i)=Z^{R} N_{t-1}^{P}(i)$. Finally, the productive bank also has incoming deposits totaling $p_{t} D_{t}^{P}(i)$. At the same time, the productive bank has outflows of newly originated unsecured and secured loans totaling $p_{t} B_{t}^{P}(i)+p_{t}^{N} N_{t}^{P}(i)$ and maturing deposits from period $t-1$ totaling 
$p_{t-1} D_{t-1}^{P}(i) r_{t-1}^{D}$. This is stated more concisely below in (30) which defines the productive bank's period $t$ nominal profits.

$$
\begin{aligned}
p_{t} \Pi_{t}^{P}(i) & =\left(1-F_{t-1}\left(\bar{\omega}_{t}\right)\right) r_{t-1}^{B, P}(i) p_{t} B_{t-1}^{P}(i)+(1-\mu) \frac{B_{t-1}^{P}(i)}{B_{t-1}} p_{t} \Phi_{t-1}\left(\bar{\omega}_{t}\right) \\
& +\left(1-F_{t-1}\left(\bar{\omega}_{t}\right)\right) p_{t-1}^{N} N_{t-1}^{P}(i) r_{t-1}^{D}+F_{t-1}\left(\bar{\omega}_{t}\right) p_{t}^{H} Z^{R} N_{t-1}^{P}(i) \\
& -p_{t} B_{t}^{P}(i)-p_{t}^{N} N_{t}^{P}(i)-p_{t-1} D_{t-1}^{P}(i) r_{t-1}^{D}+p_{t} D_{t}(i)
\end{aligned}
$$

The productive bank's ability to liquidate repossessed collateral - $N_{t}^{P}$ at zero marginal cost raises a moral hazard. In particular, if the productive bank were to claim default on all the secured loans originated in period $t$ and repossess the collateral the following period, they would earn a gross real return totaling $N_{t}^{P} \mathbb{E}_{t}\left\{\frac{Z^{R} P_{t+1}^{H}-\left(1-F_{t}\left(\bar{\omega}_{t+1}\right) R_{t}^{D} P_{t}^{N}\right)}{P_{t}^{N}}\right\}$. The first term represents income from the selling the unlawfully repossessed collateral and the second term subtracts the foregone income that would have been received from entrepreneurs paying back their loans. I assume a fraction of this return will be lost when taken so that productive banks only net a fraction $\psi_{t}^{N, P}$ of this return. This varies stochastically according to the $\operatorname{AR}(1)$ process.

$$
\ln \left(\psi_{t}^{N, P}\right)=\left(1-\rho_{\psi^{N, P}}\right) \overline{\psi^{N, P}}+\rho_{\psi^{N, P}} \ln \left(\psi_{t-1}^{N, P}\right)+\varepsilon_{t}^{\psi^{N, P}} \quad \varepsilon_{t}^{\psi^{N, P}} \sim \mathcal{N}\left(0, \sigma_{\psi^{N, P}}\right)
$$

These disturbances provide a model equivalent to the large bank share shock from that will be analyzed in the VAR.

If the productive bank chooses to abscond with the assets, entrepreneurs are entitled to the remaining equity of the bank after preferred shareholders (households) receive their risk premium. Hence, entrepreneurs would be entitled to a claim of $\left(1-\psi_{t} F_{t}\left(\bar{\omega}_{t+1}\right)\right) B K_{t}^{P}(i)$. Thus, the incentive for productive banks to claim default and abscond with these 'off-balance sheet' assets is eliminated when the equity claims of exploited entrepreneurs exceeds the gross return on unlawful liquidations.

$$
\underbrace{\left(1-\psi_{t} F_{t}\left(\bar{\omega}_{t+1}\right)\right) B K_{t}^{P}(i)}_{\text {Equity Claim of Exploited Entrepreneurs }} \geq \underbrace{N_{t}^{P} \mathbb{E}_{t}\left\{\frac{Z^{R} P_{t+1}^{H}-\left(1-F_{t}\left(\bar{\omega}_{t+1}\right) R_{t}^{D} P_{t}^{N}\right)}{P_{t}^{N}}\right\} \psi_{t}^{N, P}}_{\text {Gross Return on Unlawful Repossessions }}
$$

When (29) holds with equality, the productive bank will be limited in how many offbalance sheet assets it can hold. Moreover, this constraint will endogenously loosen and tighten in response to various macroeconomic shocks which affect home prices or default 
rates. Let $\Lambda_{t}$ denote the household's stochastic discount factor used for valuing future real payments. The problem faced by the productive bank is then defined below.

$$
\max _{\left\{r_{t+j}^{B, P}(i), B_{t+j}^{P}(i), N_{t+j}^{P}(i), D_{t+j}^{P}(i)\right\}_{j=0}^{\infty}} \sum_{j=0}^{\infty} \mathbb{E}_{t}\left\{\Lambda_{t+j} \Pi_{t+j}^{P}(i)\right\} \quad \text { subject to } \quad(22),(23),(29)
$$

Due to the complications that arise from solving a model with an occasionally binding constraint, I calibrate the model so that the productive bank's moral hazard constraint binds in the non-stochastic steady-state.

\section{Unproductive Bank}

The unproductive bank is identical to the productive bank with one noticeable exception - they are less productive. To make matters more concrete, when a secured loan defaults the unproductive bank repossesses collateral $F_{t-1}\left(\bar{\omega}_{t}\right) N_{t-1}^{U}(i)$. Unlike their productive counterparts, the unproductive bank liquidates this collateral while bearing an increasing marginal cost. On defaulted secured loans, the unproductive bank transforms repossessed collateral into housing yielding revenue $p_{t}^{H} Z^{R} N_{t-1}^{U}(i)$ at a resource cost of $p_{t} \mu^{R, U}\left(N_{t-1}^{U}(i)\right)^{\chi^{R, U}}$. This captures the heterogeneity between commercial banks (described in section 2.1) with regards to their ability to evaluate and trade off-balance sheet assets. Most notably, as unproductive banks increase their holding of these assets, the value of the assets will fall due to the increasing marginal cost. Hence, the market liquidity of such assets depends on who is holding them. A point first made by KM and applied to here to housing backed securities within this model.

With this exception, the unproductive bank's profit function is very similar to the productive bank's stated below.

$$
\begin{aligned}
p_{t} \Pi_{t}^{U}(i) & =\left(1-F_{t-1}\left(\bar{\omega}_{t}\right)\right) r_{t-1}^{B, U}(i) p_{t} B_{t-1}^{U}(i)+(1-\mu) \frac{B_{t-1}^{U}(i)}{B_{t-1}} p_{t} \Phi_{t-1}\left(\bar{\omega}_{t}\right) \\
& +\left(1-F_{t-1}\left(\bar{\omega}_{t}\right)\right) p_{t-1}^{N} N_{t-1}^{U}(i) r_{t-1}^{D, U} \\
& +F_{t-1}\left(\bar{\omega}_{t}\right)\left[p_{t}^{H} Z^{R} N_{t-1}^{U}(i)-p_{t} \mu^{R, U}\left(N_{t-1}^{U}(i)\right)^{\chi^{R, U}}\right] \\
& -p_{t} B_{t}^{U}(i)-\chi^{B, U} B_{t}^{U}(i)-p_{t}^{N} N_{t}^{U}(i)-p_{t-1} D_{t-1}^{U}(i) r_{t-1}^{D}+p_{t} D_{t}^{U}(i)
\end{aligned}
$$

Notice the lack of productivity spills over to unsecured loans. The parameter $\chi^{B, U}$ is calibrated to match the average share of resources allocated to financial intermediation. The increasing resource cost of repossessing collateral implies the unproductive bank is not subject to a moral hazard constraint. In particular, if any single unproductive bank $i$ attempted to purchase a large amount of these assets at a given market price $p_{t}^{N}$ and falsely claim 
default, their cost of liquidating the assets would exceed what they paid for them. Therefore the existence of these increasing marginal cost eliminates any incentive to steal away these assets.

Let $\Lambda_{t}$ denote the household's stochastic discount factor used for valuing future real payments. The problem faced by the unproductive bank is then defined below.

$$
\max _{\left\{r_{t+j}^{B, U}(i), B_{t+j}^{U}(i), N_{t+j}^{U}(i), D_{t+j}^{U}(i)\right\}_{j=0}^{\infty}} \sum_{j=0}^{\infty} \mathbb{E}_{t}\left\{\Lambda_{t+j} \Pi_{t+j}^{U}(i)\right\} \quad \text { subject to }
$$

\subsubsection{Central Bank}

The central bank is charged with setting a macroprudential policy rule and a monetary policy rule. The macroprudential policy instrument is the regulatory maximum share of capital that can be allocated to loan losses. This essentially controls the amount of owners equity the bank can allocate to cover loan losses. Here, I assume the central bank simply sets this to a constant level.

$$
\psi_{t}=\bar{\psi}
$$

As for the monetary policy instrument I assume the central bank follows the simple interest rate rule whereby the rate on one-period deposits adjusts to the inflation rate where $\pi_{t}=\frac{p_{t}}{p_{t-1}}$.

$$
\left(\frac{r_{t}^{D}}{r^{D}}\right)=\left(\frac{\pi_{t}}{\bar{\pi}}\right)^{\phi_{\pi}}
$$

\subsubsection{Market Clearing}

Sections 3.2.1 - 3.2.5 describe the optimal behavior of all agents in the economy. A symmetric competitive equilibrium is defined as a sequence of quantities, prices and Lagrange multipliers (shadow prices) which satisfy all optimality conditions, policy rules and market clearing conditions. In particular, the demand for housing must equate the supply of housing on the market which consists of newly built homes, repossessed collateral being liquidated on the housing market and non-depreciated housing from last period. Put more simply,

$$
H_{t}=H_{t}^{N e w}+F_{t-1}\left(\bar{\omega}_{t}\right) Z^{R}\left(\nu N_{t-1}^{U}+(1-\nu) N_{t-1}^{P}\right)+\left(1-\delta^{H}\right) H_{t-1} .
$$

The above expression can be further simplified by noting that the market for secured lending (or more narrowly, land) clears when

$$
\bar{N}=\nu N_{t}^{U}+(1-\nu) N_{t}^{P}
$$


where the left hand side is the aggregate endowment of entrepreneurs. By the ex-ante symmetry among entrepreneurs this is required to equal $\bar{N}=\bar{N}^{j}$ for all home builders $j$. Similarly, this ex-ante symmetry also implies the demand for capital by entrepreneurs is identical, or $K_{t}=K_{t}^{j}$ for all entrepreneurs $j$. I assume that capital can be transformed one for one from the final good and depreciates at rate $\delta^{K}$. Therefore, capital evolves according to,

$$
K_{t}=I_{t}+\left(1-\delta^{K}\right) K_{t-1} .
$$

Since I do not include adjustment costs, the price of capital equals the price of the final good at all times, $q_{t}=p_{t}$. Adjustment costs in the production of capital could easily be added, as in BGG. However, in this model, they are not needed to generate an amplification effect. Instead, the asset price spirals occur from the redistribution of assets between agents as in KM. With this description of the model, the goods market clearing condition is satisfied whenever,

$$
Y_{t}=C_{t}+C_{t}^{E}+I_{t}+I_{t}^{B K}+\mu \Phi_{t-1}\left(\bar{\omega}_{t}\right)+\nu \mu^{R, U}\left(N_{t-1}^{U}(i)\right)^{\chi^{R, U}}+\nu \chi^{B, U} B_{t}^{U},
$$

which stipulates that the consumption good must be either consumed by the household or the entrepreneur, invested in bank capital, or used to audit or repossess the collateral of defaulting entrepreneurs. It is useful for the purpose of calibration and model inference to define GDP in this multi-sector model.

$$
G D P_{t}=C_{t}+I_{t}+P_{t}^{H} H_{t}^{N e w}
$$

\subsection{Calibration}

The model is calibrated to match characteristics of the U.S. economy from 1998 to 2012 and each time period is interpreted as one quarter. In order to numerically solve the model, there are 23 non-shock parameters and 15 shock parameters which must first be assigned values. Beginning with the household's parameters I calibrate $\beta=.99$ as to match up the steady state deposit rate in the model with the average rate on 3-Month U.S. Treasury Bills. I set the utility on non-housing leisure and housing leisure, $\eta^{L^{H}}=7.43$ and $\eta^{L}=1.88$ which matches the share of labor supplied in housing equal to 5\%, the U.S. average using data from the BLS and the total share of time spent working equal to $1 / 3$. Finally, the last of the preference parameters $\overline{\eta^{H}}=.2352$ calibrates the steady state real price of housing so that consumption's share of GDP $=\frac{C}{G D P}=.79$, which is the average ratio of personal consumption expenditures to personal consumption expenditures and private investment for the U.S. Similarly, setting $\delta^{H}=.021$ implies the share of housing wealth to annual GDP, $\frac{P^{H} H}{4 \times G D P}=1.4$. 
On the production side, I set the share of income going to labor in the goods producing sector, $1-\alpha_{G}=.7$ and the same share in the housing sector $1-\alpha_{H}=.8$ following Iacovello and Neri (2010). I normalize the 'land' endowment of entrepreneurs, $\bar{N}=1$. As for the financial accelerator parameters, I collectively set $\mu^{M}=.14$ and $\overline{\sigma^{\omega}}=.21$. The auditing cost parameter falls between the value from Christiano, Motto, and Rostagno (2013) and BGG and the steady state value of the variance of the idiosyncratic productivity shock implies an annual steady state default rate of $F(\bar{\omega})=.01$ which is the average default rate on C \& I loans secured by real-estate using date obtained from the St. Louis Fed's FRED database.

With regards to the banking sector, I set the share of capital allocated to loan losses, $\psi=$ .25 , the average of loan-loss allocations to the equity of commercial banks over this period according to data obtained from FRED. I normalize each bank's share of the population to be equal by setting $\nu=\frac{1}{2}$. The depreciation rate on capital is set at $\delta^{B K}=.08$ for a baseline calibration, following Gerali, Neri, Sessa, and Signoretti (2010). The value for $\nu \chi^{B, U}=.0004954$ is obtained from Hafstead and Smith (2012) who create a time series of banking productivity in loan intermediation. I set the steady-state rate of return on entrepreneurial loans equal to the average prime loan rate, $r^{E}=1.017$. This pins down the elasticity of substitution between bank loans, $\theta_{B}=157.21 .^{10}$ There is little agreement over the real return on capital, I set it equal to equal to $10 \%$ per annum which is slightly below the real return on capital in the U.S. estimated by Oulton and Rincon-Aznar (2009). ${ }^{11}$ This value also matches the annualized return on small-cap stocks, representing firms who are likely to be financially constrained, using data from Morningstar.

I set $\bar{\gamma}^{P}=.003$ and $\bar{\gamma}^{U}=.001$. These values simply ensure the transfers made to the household for exposing equity to loan losses, is made up for with equity injections sufficient to guarantee a positive steady-state level of bank capital. Similarly, setting $\overline{\psi^{N, P}}=.12$ implies in steady state, the share of 'Off-balance sheet assets' held by the productive banks, $\frac{N^{P}}{N^{P}+N^{U}}=.92$, the average share of total credit exposure concentrated in large banks as explained in Section (2.1). Additionally, I set $\chi^{R, U}=1.06$, implying strictly convex cost of repossessing/liquidating collateral for the unproductive bank. This value is adjusted in the simulations below. This together with setting $\mu^{R, U}=0.2755$ calibrates the steady state price of the 'Off-balance sheet assets' so that $\frac{P^{N} \bar{N}+B}{P^{N} \bar{N}}=2.5$, or the average ratio of C\&I loans plus total credit exposure to total credit exposure. Finally, normalizing $Z^{R}=1$ and setting $\bar{Z}^{H}=1.14$ implies the real-estate owned share, or REO share, $\frac{F(\bar{\omega}) Z^{R} \bar{N}}{F(\bar{\omega}) Z^{R} \bar{N}+H^{N e w}}=.1775$ which is the value in the data according to RealtyTrac.

\footnotetext{
${ }^{10}$ Hafstead and Smith (2012) find a similarly high value for $\theta_{B}=260$.

${ }^{11}$ Oulton and Rincon-Aznar (2009) estimate the average annual real return on capital to be $13 \%$, however they acknowledge this estimate is potentially biased upwards. Therefore, I follow Hafstead and Smith (2012) and set the annual return to $10 \%$.
} 
As for the remaining policy parameters, steady state gross inflation is set equal to unity and $\phi_{\pi}=2.0$ following an OLS estimation of (32) using data on the effective federal funds rate and the percent change of the core personal consumption expenditure's deflater. The results are essentially unchanged if Taylor's (1993) value of $\phi_{\pi}=1.5$ is used. The remaining shock parameters can not be pinned down by matching steady state values. The exogenous process, $\psi_{t}^{N, P}$, which governs the productive bank's moral hazard constraint is used to highlight the impact of asset redistribution between banks, and is largely not structural. Therefore, I set $\rho_{\psi^{N, P}}=.9$ and $\sigma_{\psi^{N, P}}=.01$.

The remaining exogenous processes are calibrated using a moments matching exercise. In particular, I choose $\rho_{Z^{G}}=0.9338, \sigma_{Z^{G}}=0.0157, \rho_{Z^{H}}=0.6998, \sigma_{Z^{H}}=0, \rho_{\eta^{H}}=0.8959$, $\sigma_{\eta^{H}}=0.0665, \rho_{\sigma^{\omega}} 0.8898$ and $\sigma_{\sigma^{\omega}}=0.0455$ to match the long-run standard deviation and first-order autocorrelation of: the external finance premium (proxied by the spread between BAA corporate bond-rate and 10-year treasuries), real $\mathrm{GDP}^{12}$, real private investment and real home prices. This exercise not only pins down values for the model's driving shocks, but since I do not restrict the calibration strategy to match the model's implied correlation matrix, it allows for an empirical examination of the model's performance.

Table 1: Cyclical Properties of the Model

\begin{tabular}{|c|c|c|c|c|c|}
\hline Correlation & 5 Percent & Median & 95 Percent & Model & BGG (1999) \\
\hline EFP, GDP & -0.89 & -0.68 & -0.45 & -0.82 & 0.03 \\
\hline $\mathrm{EFP}, P^{H}$ & -0.87 & -0.60 & -0.32 & -0.68 & 0.18 \\
\hline EFP, Investment & -0.89 & -0.63 & -0.32 & -0.88 & -0.18 \\
\hline $\mathrm{GDP}, P^{H}$ & 0.50 & 0.76 & 0.93 & 0.89 & 0.84 \\
\hline GDP, Investment & 0.93 & 0.96 & 0.99 & 0.93 & 0.79 \\
\hline$P^{H}$, Investment & 0.57 & 0.81 & 0.95 & 0.68 & 0.42 \\
\hline
\end{tabular}

a The data correlations and confidence intervals are computed using Jeffery's Prior and 5000 draws from the resulting posterior distribution of an estimated $\operatorname{VAR}(2)$.

The model fits the data reasonably well with all moments in the confidence interval. Comparing this model to the baseline BGG model augmented with a housing sector, it becomes clear why the celebrated BGG financial accelerator must be adjusted to analyze the financial crisis. The BGG financial contract assumes the borrowers wealth is liquid, therefore (real-estate) secured debt is absent in the model. This explains why BGG has

\footnotetext{
${ }^{12}$ Real GDP is measured as the model equivalent. Hence, I sum personal consumption expenditures and private investment and deflate the resulting series by the civilian population over the age of 16 and the personal consumption expenditures excluding food and energy price deflator.
} 
difficulty capturing the dynamics between the EFP and both $P^{H}$ and Investment. BGG's counterfactual correlation between GDP and the EFP stems largely from the documented puzzle that BGG's debt-contract generates an increases in the EFP following a positive technology shock. (Shen, 2011). These issues are absent in the model presented here since housing secured debt, and therefore home prices, play a critical role in the financial contract.

\subsection{The Model's Amplifying Effect of Asset Redistribution}

In this section I analyze the behavior of the following four variables:

1. External Finance Premium $(\mathrm{EFP})=\mu \frac{\phi_{t-1}\left(\bar{\omega}_{t}\right)}{B_{t-1}}$

2. Real GDP $=G D P_{t}$

3. Real house prices $=P_{t}^{H}$

4. The share of off-balance sheet assets held by large banks $=\frac{(1-\nu) N_{t}^{P}}{\bar{N}}$

in response to the model's structural shocks. For each set of impulse response functions, I present the model's response when the productive bank's moral hazard constraint binds (the solid lines) and when this constraint is relaxed (the dashed lines). Notice that when the constraint is relaxed, the productive banks hold all of the 'Off-balance sheet' assets since they are significantly more productive. Hence, for this model, the Large Bank Share variable is constant.

Figure 4 displays the equilibrium model's response of the endogenous variables to a detrimental risk shock, positive technology and housing demand shocks and an increase in the share of off-balance sheet assets held by the productive banks. The dynamics are noticeably different when the moral hazard constraint binds compared to the efficient allocation whereby large banks hold all of the off-balance sheet assets. In particular, the response of all the variables are amplified. Changes in the risk-characteristics of borrowers or the household's preferences towards housing are magnified by a factor of 2 when assets are redistributed between large and small banks. Even technology shocks raise GDP by $25 \%$ more at peak when large banks are able to expand their off-balance sheet asset holdings. The key factor driving these changes are movements in home prices, which are themselves amplified.

I highlight this amplification effect in figure 5 which illustrates the differences between the two models simulated in the IRFs. The diagram shows the effect of a drop in home prices on the price of $\bar{N}$. In particular, the equation determining the price of 'Off-balance sheet assets' is given by the unproductive banks first order condition for $N_{t}^{U}$,

$$
P_{t}^{N}=\frac{1}{R_{t}^{D}} \mathbb{E}_{t}\left\{Z^{R} P_{t+1}^{H}-\chi^{R, U} \mu^{R, U} N_{t}^{U}\left(\chi^{R, U}-1\right)\right\}
$$




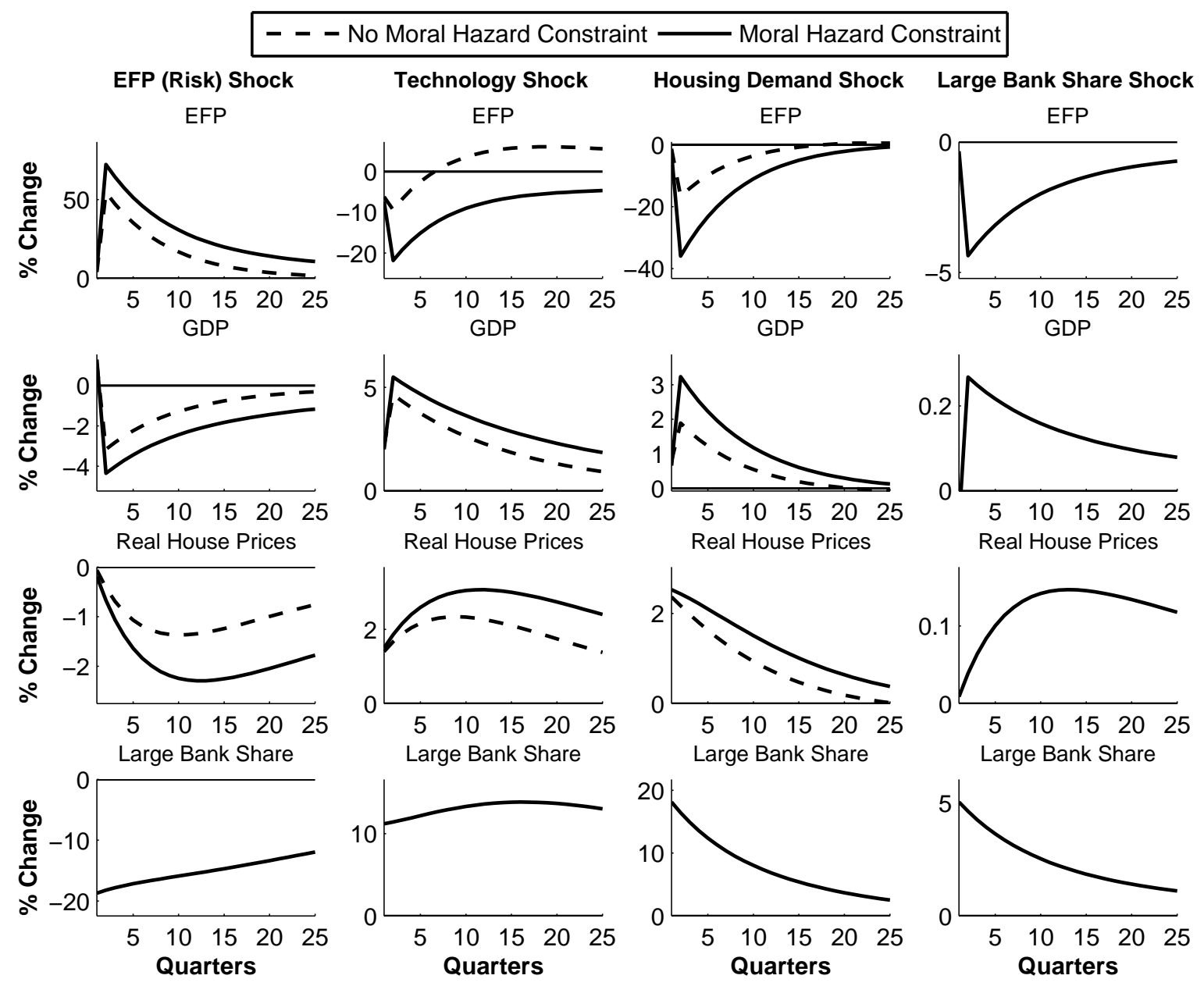

Figure 4: Impulse response functions from the equilibrium model. The solid lines denote the dynamic responses when the productive bank's moral hazard constraint binds and the dashed lines are the dynamics when this constraint is relaxed.

which for $\chi^{R, U}>1$ looks like a typical demand curve. If expected home prices fall, this will shift down the demand curve for these assets. Without any redistribution effect, asset prices fall from $P_{1}^{N}$ to $P_{1}^{N^{\prime}}$ - this is the dynamic captured in the figure on the left.

To understand the amplification effect stemming from the redistribution of off-balance sheet assets, notice two things. (i) First, due to the positive marginal cost of liquidating 

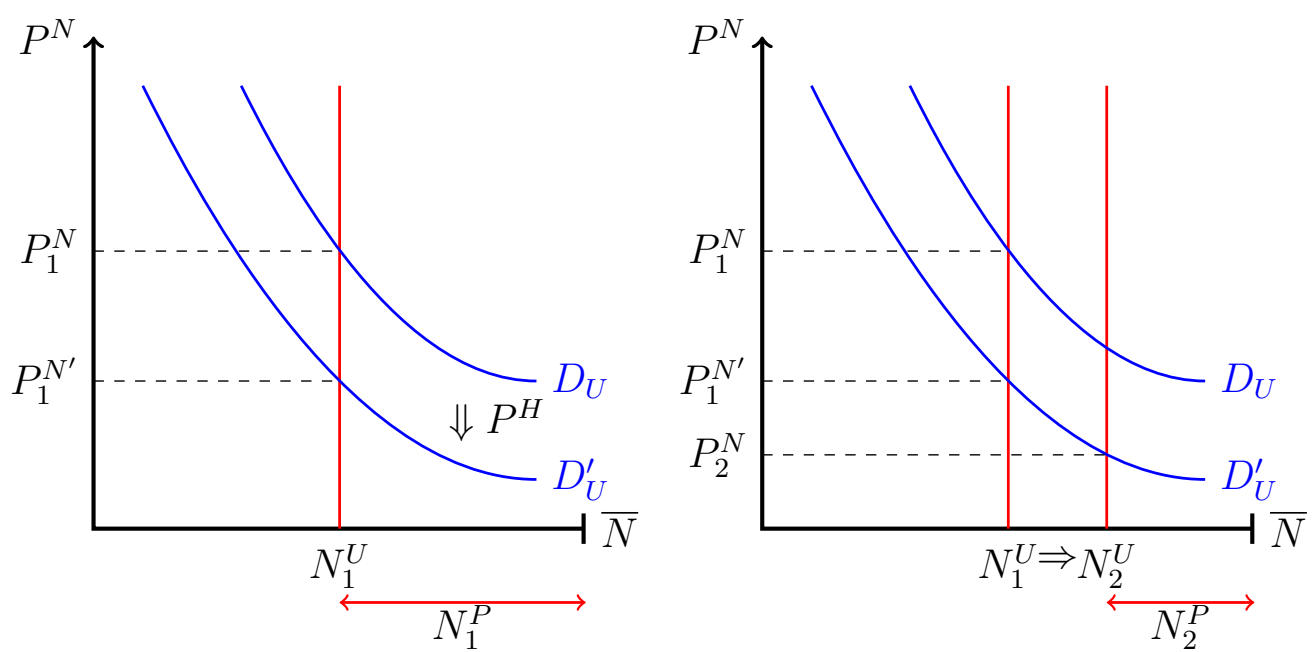

Figure 5: The graph on the left illustrates the impact on asset prices when home prices drop, without any redistribution effect. The graph on the right highlights the additional fall in asset prices that results when the productive bank must reduce its share of off-balance sheet secured assets due to the endogenously tightening moral hazard constraint.

collateral, asset prices fall by more (in percentage terms) than expected home prices. That is, $\mathcal{E}_{P_{t}^{N}, \mathbb{E}_{t}}\left\{P_{t+1}^{H}\right\}>1$.

$$
\mathcal{E}_{P_{t}^{N}, \mathbb{E}_{t}\left\{P_{t+1}^{H}\right\}}=\frac{\partial P_{t}^{N}}{\partial \mathbb{E}_{t}\left\{P_{t+1}^{H}\right\}} \frac{\mathbb{E}_{t}\left\{P_{t+1}^{H}\right\}}{P_{t}^{N}}=\frac{Z^{R} \mathbb{E}_{t}\left\{P_{t+1}^{H}\right\}}{Z^{R} \mathbb{E}_{t}\left\{P_{t+1}^{H}\right\}-\chi^{R, U} \mu^{R, U} N_{t}^{U} \chi^{R, U-1)}}>1
$$

(ii) Second, the debt contract described in section 3.2.2 shows that as the value of the entrepreneur's pledgeable assets falls, the probability of default increases. ${ }^{13}$

$$
\frac{\partial F_{t}\left(\bar{\omega}_{t+1}^{j}\right)}{\partial P_{t}^{N}}=\frac{\partial F_{t}\left(\bar{\omega}_{t+1}^{j}\right)}{\partial \bar{\omega}_{t+1}^{j}} \frac{\partial \bar{\omega}_{t+1}^{j}}{\partial P_{t}^{N}}>0
$$

These two effects, (i) and (ii) (Eqs. 39 and 40 ), both act to tighten the binding moral hazard constraint for the productive bank (Eq. (29)) and hence the large bank share falls. This is illustrated in the graph on the right of figure 5. In particular, a drop in home prices

\footnotetext{
${ }^{13}$ The first partial derivative is positive due to the monotonicity of CDFs and the second partial derivative is positive due to the structure of the optimal debt contract.
} 
induces not only a direct fall in asset prices from $P_{1}^{N}$ to $P_{1}^{N^{\prime}}$ but a further drop to $P_{2}^{N}$ due to an endogenous reduction in $N_{t}^{P}$ (and the downward sloping demand for $N_{t}^{U}$ due to the strictly convex costs). This is the beginning a multiplier effect of sorts. As $P_{t}^{N}$ falls by more than $\mathbb{E}_{t}\left\{P_{t+1}^{H}\right\}$, the moral hazard constraint tightens further inducing further reductions in $N_{t}^{P}$. All the while, as these forces act to push down the value of secured debt, borrower's face an increasing external finance premium. This is the amplification effect highlighted by the difference between the 2 sets of IRFs in figure 4.

This static multiplier effect from asset redistribution may be easiest to spot when I exogenously increase the share of assets held by the productive bank. The dynamics following this exogenous shock are shown in the the last column of IRFs in figure 4. Although, the shock is set to increase $N_{t}^{P}$ by only $1 \%$ the period the shock hits, $N_{t}^{P}$ increase more than 5 times as much, above 5\%. Again, this amplified response is driven by the asset redistribution illustrated in figure 5. When $N_{t}^{P}$ increases there are two immediate effects, as explained by equations 39 and 40, both of which act to expound this increase in the productive bank's share of off-balance sheet assets.

One common them through all the impulse response functions is an amplification effect stemming from asset redistribution. Although, I have highlighted the static amplification, there is also a dynamic feature at work which makes the moral-hazard constrained model more persistent. Since repossessed collateral ultimately is liquidated on the real-estate market, this increase in supply lowers home prices into the future to the extent that housing does not depreciate immediately. These effects re-enforce one another over time. Ultimately though, these dynamic amplification effects are powered by restarting, period by period, the engine that drives the static multiplier.

\section{A Factor Structural VAR}

In this section, I estimate a VAR to examine the empirical plausibility of the model's predictions. Included in the VAR are the same variables examined in the model's impulse response functions: the external finance premium, real GDP, real home prices and the share of total credit exposure concentrated in large banks. All variables are available at a quarterly frequency from 1998:Q2 to 2012:Q4. ${ }^{14}$ As specified in log-levels, the Schwarz Bayesian information criterion selects 2 lags for the VAR. In what follows I first lay-out the model's testable predictions, then I go on to describe the data and the structural identification before presenting the impulse response functions.

\footnotetext{
${ }^{14}$ The time series is limited by the availability of net credit exposure data from the OCC's Quarterly Derivatives Report. However, for the removal of time-trends, I use data going back to 1975:Q1
} 


\subsection{The Model's Empirical Implications}

The DSGE model developed in the previous section posits an amplification effect stemming from the redistribution of assets between large and small banks. In particular, the model makes 3 clear predictions:

1. Increases in the risk characteristics of borrowers, proxied by increases in the external finance premium, reduces the concentration of off-balance sheet assets in large commercial banks.

2. Increases in real value of homes, due to an increase in housing demand or a technological advancement, improves the financial position of borrowers and increases the concentration of off-balance sheet assets in large banks.

3. Finally, the model predicts that as assets shift to large banks, finance premiums fall resulting in higher GDP and real home prices.

These predictions come directly out of the model's impulse responses in Figure 4. The first prediction states that when the demand-side financial friction worsens, the economy contracts and the supply-side financial friction worsens as well, forcing large banks to deleverage. The second point above predicts that an aggregate expansion improves both the demandside friction and the supply-side friction. Finally, the third prediction summarizes that a tightening supply-side constraint will cause the economy to contract and ultimately result in a tightening of the demand-side financial friction. In this section I use a factor structural VAR to empirically test these predictions. The results of this empirical exercise supports the model predictions, providing empirical support for the 2-sided financial frictions and their interaction as modeled in this paper.

\subsection{Data Description}

One of the model's key variables, the external finance premium is unobservable. However, following the recent strategy of Christiano, Motto, and Rostagno (2013) and Carlstrom, Fuerst, Ortiz, and Paustian (2012), I use the spread between BAA corporate bonds and 10-year Treasuries to proxy this unobservable variable. As for real GDP, I use the model equivalent definition. I sum personal consumption expenditures and private investment (the sum of residential and non-residential investment in the model) and divide the resulting series by the personal consumption expenditures excluding food and energy price deflater. I measure real home prices using the Case-Shiller National Composite Home Price Index divided by the personal consumption expenditures excluding food and energy price deflater. Both real GDP and real home prices reveal evidence of a unit root at the $10 \%$ confidence level using an ADF test. I therefore, remove any deterministic and/or stochastic trend by 
taking the difference between the log of the original series and a 25 quarter centered moving average of the logged series. Finally, construction of the large bank share variable is discussed in Section (2).

\subsection{Identification}

The model's implications described above calls for the identification of 3 distinct structural shocks using four variables. Since the number of desired structural shocks is less than the number of variables for which there are model implications, I employ a factor structural vector auto-regression following Gorodnichenko (2005). This approach is appropriately fitting here for a couple of reasons. First, the four variables in the VAR behave qualitatively similar to technology and housing demand shocks in the equilibrium model as shown in Figure 4. For this reason, imposing timing restrictions at any horizon to distinguish these shocks proves difficult. Moreover, there is no need to disentangle these shocks to test the model's predictions that an aggregate expansion which increases real home prices, loosens both the supply and demand side financial frictions. Therefore, I choose to simply recognize macroeconomic disturbances as a single factor, which allows me to test the model's prediction along this dimension without imposing arbitrary timing restrictions on the behavior of output and real home prices. Blanchard and Quah (1989) make a similar argument that shocks can be aggregated when they elicit qualitatively similar dynamics. ${ }^{15}$ Second, the external finance premium in the model is unobservable. Hence, by using a factor-structural VAR, I can explicitly include measurement error terms to ensure this proxy for the external finance premium does not contaminate the structural shocks of study.

In addition to the macroeconomic factor discussed above, I identify a 'risk' shock, an increase in the cross sectional dispersion of borrowers in the model $\ln \left(\sigma_{t}^{\omega}\right)$ and an exogenous increase in the share of off-balance sheet assets held by large banks. The latter shock is the model equivalent of a decrease in $\ln \left(\psi_{t}^{N, P}\right)$ which exogenously improves the moral hazard problem between large banks and borrowers. To summarize, I identify an exogenous tightening of the demand-side financial friction (the 'risk' shock), a beneficial macroeconomic shock and an exogenous loosening of the supply-side financial friction. Identifying these three shocks is sufficient to test the three model predictions laid out above.

To identify these three shocks, I impose a recursive scheme that ensures global identification is achieved ${ }^{16}$ and allows for home prices and real GDP to behave symmetrically to all

\footnotetext{
${ }^{15}$ Their argument is a bit more formal. To summarize, they show that so long as the dynamic responses of the variables in the VAR to the aggregated shocks differ up to a scalar lag distribution (The responses need not be identical nor proportional) then the shocks can be aggregated.

${ }^{16}$ Since the $3 \times 3$ sub-matrix of A excluding the last row is lower triangular, we can ensure global identification (Anderson, 2003; Anderson and Rubin, 1956).
} 
the shocks. In the model, the ex-post observable external finance premium in period $t$ is determined by fundamentals in period $t-1$. For this reason, I order the spread, which proxies the external finance premium first in the VAR to match this feature of the model. Next I order real GDP and then home prices. The ordering between these two variables is innocuous since they are treated symmetrically in the identification scheme. Finally, I order the share of total credit exposure held by large banks. This recursive ordering is consistent with the equilibrium model. The macroeconomic factor shocks in the DSGE model do not have a contemporaneous effect on the external finance premium but they do contemporaneously impact real GDP, real home prices and the large bank share. Additionally, the supply-side financial shock affects all variables (other than the large bank share) with a lagged response.

To summarize the identification scheme, let $e_{t}$ denote the $4 \times 1$ vector of reduced form VAR residuals. Let $\epsilon_{t}$ denote the $3 \times 1$ vector of structural shocks and let $v_{t}$ denote the $4 \times 1$ vector of measurement errors which ensures the rank between the reduced form shocks and the identify structure match. The matrix $A$, is a $4 \times 3$ loading matrix which relates the structural factors to the reduced form residuals. Summarizing this,

$$
e_{t}=A \epsilon_{t}+v_{t}
$$

where

$$
A=\left[\begin{array}{ccc}
a_{1,1} & 0 & 0 \\
a_{2,1} & a_{2,2} & 0 \\
a_{3,1} & a_{3,2} & 0 \\
a_{4,1} & a_{4,2} & a_{4,3}
\end{array}\right]
$$

I assume the measurement error terms, $v_{t}$ are independent of the structural factors $\epsilon_{t}$ at all leads and lags and I also assume the covariance matrix of the measurement errors, $\Psi$, is diagonal. Equation (41) is estimated using maximum likelihood techniques. ${ }^{17}$

\subsection{Impulse Response Functions}

Impulse response functions trace out the path of the variables in periods $t=0,1,2, \ldots$ in response to a one time structural disturbance in period $t=0$. The rows of figure 6 correspond to variables while the columns correspond to the structural factors described above. Confidence bands are computed using Monte Carlo integration techniques assuming a

\footnotetext{
${ }^{17}$ In particular, assuming $e_{t}$ are i.i.d. Normal, the log-likelihood equation is given by,

$$
\log (\mathcal{L})=-\frac{4 T \ln (\pi)}{2}-\frac{T}{2} \ln \left(\left|A A^{\prime}+\Psi\right|\right)-\frac{1}{2} \sum_{t=1}^{T} e_{t}^{\prime}\left(A A^{\prime}+\Psi\right)^{-1} e_{t}
$$
}



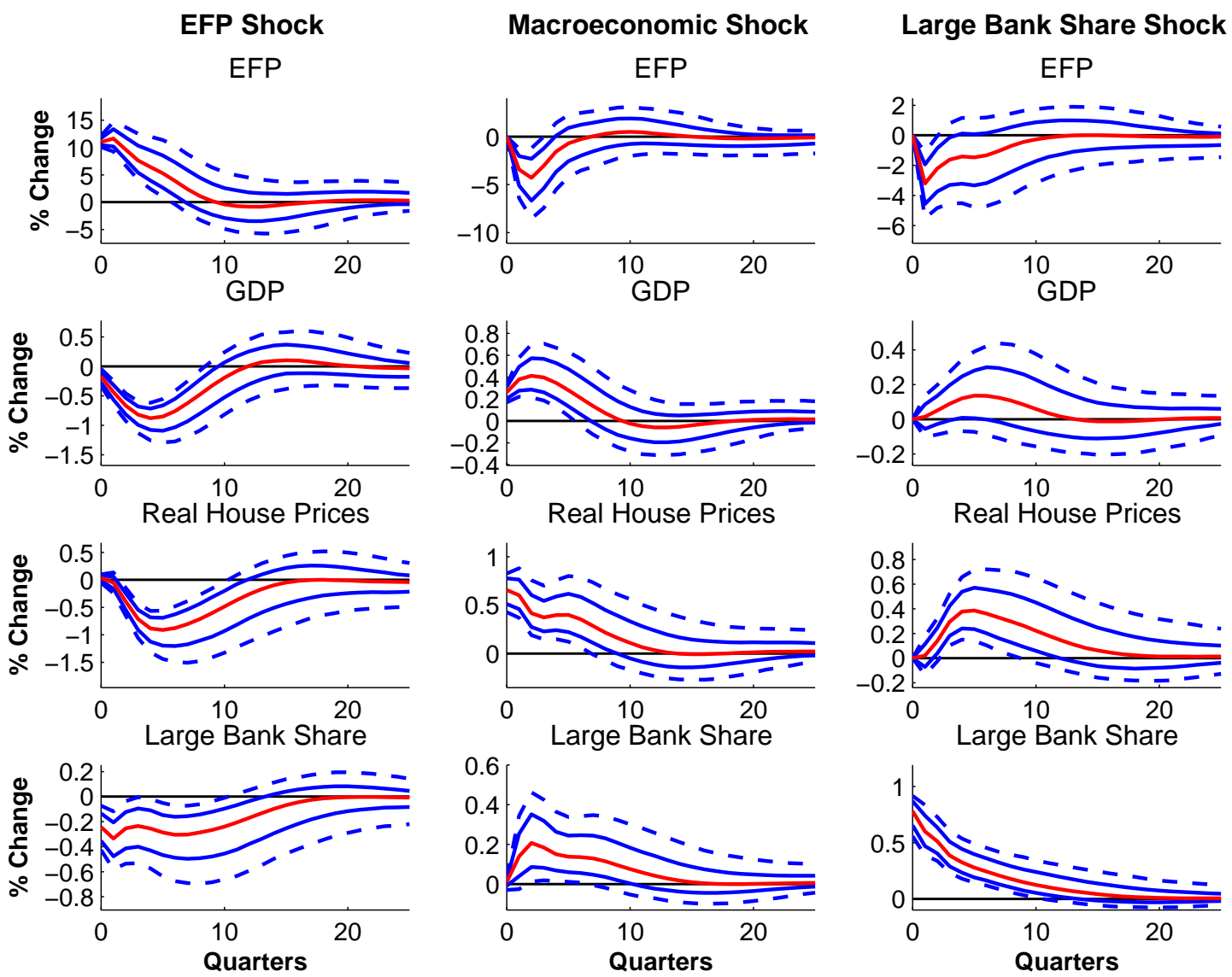

Figure 6: Median Impulse Response Functions with 68\% and 90\% confidence bounds computed with 5000 draws from the posterior distribution using Jeffery's Prior.

normal likelihood and uninformative prior. In column 1, the external finance premium shock looks as expected with an exogenous increase in the finance premium increasing defaults and ultimately lowering home price due to the increased supply of homes on the market. As home prices fall so too does real GDP. Importantly, the large bank share falls in response to such disturbances. This confirms the first prediction of the model, an exogenous tightening of the demand-side financial friction, causes off-balance assets to shift to smaller banks.

The second structural shock is the macroeconomic factor which simultaneously increases real home prices and real GDP. This has the interpretation of either a housing demand 
disturbance or a technology shock in the DSGE model. Both shocks have been attributed as playing a driving role in the evolution of the real economy (See for example Kydland and Prescott (1982) or Iacoviello and Neri (2010)). As the model predicts, a beneficial aggregate disturbance improves borrower's collateral values and hence financial position resulting in lower external finance premiums. Moreover, the model predicts this beneficial shock will loosen the large banks moral hazard constraint allowing them to take on more assets. This feature is confirmed in the VAR.

Finally, I order the share of credit exposure concentrated in large banks. The model's key prediction is that changes in this distribution alter the finance terms offered to borrowers and ultimately affect real GDP and real home prices. The data confirms this prediction. An exogenous increase in the share of assets held by large banks drops the external finance premium, suggesting financing conditions are improving. Moreover, this transmits to more investment, fewer defaults and hence higher home prices, all of which exact a positive movement in real GDP. In summary, the results above provide evidence which supports the hypothesis that the redistribution of off-balance sheet assets magnifies the movement of finance premiums, house prices and output across the business cycle, supporting the model's predictions.

\section{Unconventional Monetary Policy}

I now turn the focus to analyzing the unprecedented actions taken by policy makers in the wake of the 2007 Financial Crisis through the lens of this empirically verified model. Since the model features large financial firms ('Too Big to Fail' banks) and housing secured debt (Mortgage Backed Securities), it can be used to analyze the relative effectiveness of:

(i) Equity injections into big banks similar to TARP

(ii) Central Bank purchases of mortgage backed securities such as QE1 and QE3

To simulate these policies I hit the economy with a large decrease in housing demand which generates a 10\% drop in real GDP - similar to the magnitude of the Great Recession. I consider three alternative unconventional monetary policy regimes including no policy as simulated in Figure (4). The alternative two regimes are described below.

Equity Injections To simulate equity injections into 'Too Big to Fail' banks I assume the Central Bank uses a lump-sum tax, $T_{t}$, to raise money from the household and provide an equity injection, $I N J_{t}^{C B}$, to the productive banks. The banks can use the capital immediately but must pay it back in its entirety. This policy is modeled by 

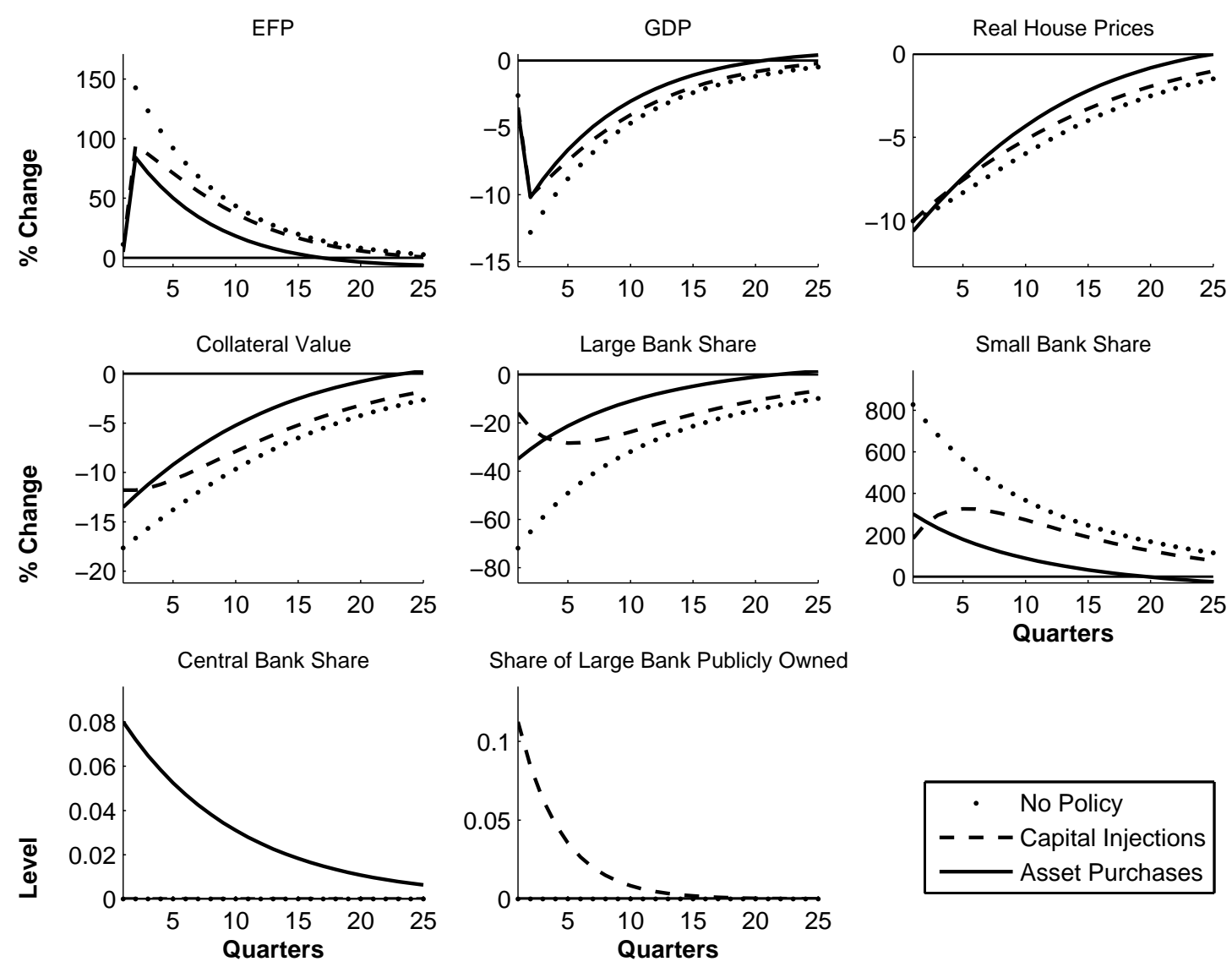

Figure 7: Impulse responses to large contraction in housing demand. The dashed lines represent the dynamics under no policy response, the solid lines are the dynamics following a short-term equity injection and the dotted line displays the dynamics under a persistent central bank asset purchase policy.

adding/augmenting the following equations to the model.

$$
\begin{aligned}
I N J_{t}^{C B} & =\theta_{B K} \varepsilon_{t}^{\eta^{H}} \\
T_{t} & =I N J_{t}^{C B}-\delta^{C B} \frac{B K_{t-1}^{C B}}{\pi_{t}} \\
B K_{t}^{C B} & =I N J_{t}^{C B}+\left(1-\delta^{C B}\right) \frac{B K_{t-1}^{C B}}{\pi_{t}}
\end{aligned}
$$

In any period $t$, the productive banks now have total capital equal to $B K_{t}^{P}+B K_{t}^{C B}$. 
This policy rule only has two parameters to calibrate. I set $\theta_{B K}=.1$ which calibrates the size of the initial equity injection and $\delta^{C B}=.25$ which implies the majority of the equity transfer is repaid in the first 2-years. This timing is consistent with the observations from the TARP policy.

Quantitative Easing: To simulate large scale asset purchases of mortgage backed securities (MBS) I assume the Central Bank uses a lump-sum tax, $T_{t}$, to raise money from the household and then purchases $P_{t}^{N} N_{t}^{C B}$ units of collateral. As the policy persists, the household will be responsible for any losses or profits from the central bank's holding of these assets. This policy is modeled by adding/augmenting the following equations to the model.

$$
\begin{aligned}
N_{t}^{C B} & =\theta_{N} \varepsilon_{t}^{\eta^{H}}+\rho_{N} N_{t-1}^{C B} \\
T_{t} & =P_{t}^{N} N_{t}^{C B}-\left(1-F_{t-1}\left(\bar{\omega}_{t}\right)\right) p_{t-1}^{N} N_{t-1}^{C B} r_{t-1}^{D}-F_{t-1}\left(\bar{\omega}_{t}\right) P_{t}^{H} Z^{R} N_{t-1}^{C B}
\end{aligned}
$$

In any period $t$, the market clearing condition for secured lending is now given by,

$$
\bar{N}=\nu N_{t}^{U}+(1-\nu) N_{t}^{P}+N_{t}^{C B} .
$$

This policy rule has two parameters to calibrate. I set $\theta_{N}=2$ which calibrates the initial size of the asset purchases and I set $\rho_{N}=.9$ to capture the prolonged nature of the Quantitative Easing policies implemented by the Federal Reserve.

\section{Equity Injections vs. Quantitative Easing}

The simulations of the large fall in housing demand are illustrated in Figure (7) under all three unconventional policy regimes - including no policy intervention. The results reveal that both equity injections and large-scale asset purchases (LSAP's) mitigate the crisis on impact. However, the duration of the unconventional policies plays a critical role in determining the time it takes to recover from the recession. Since the equity injections are (mostly) paid back after about 8 quarters, the dynamics under this regime converge towards the no-policy regime. The length of the recession is essentially unchanged - although the initial severity is lessened. Comparing equity injections to LSAP's, the equity injections better mitigate the initial impact of the crisis; however, the persistence of the LSAP policy serve to speed-up the recovery.

Which policy is preferred? To answer this question, I analyze (i) the total costs of the policies and importantly (ii) the welfare rankings of the policies using the household's utility function.

Table (2) reveals that although both unconventional policy regimes are preferred to no policy intervention, the quantitative easing policy outperforms the equity injections in terms 
Table 2: Equity Injections vs. Quantitative Easing

\begin{tabular}{lcc}
\hline \hline Policy Rule & Cost to Taxpayers & Welfare $^{1}$ \\
\hline No Policy & 0.00 & -1.32 \\
Equity Injections & 0.00 & -1.22 \\
Quantitative Easing & -0.02 & -1.05 \\
\hline \hline${ }^{1}$ Welfare is computed by evaluating $\frac{\partial \mathcal{W}_{t}}{\partial \varepsilon_{t}^{\eta H}}$ where & $\mathcal{W}_{t}=u_{t}+$ \\
$\beta \mathbb{E}_{t}\left\{\mathcal{W}_{t+1}\right\}$ and $u_{t}$ is the household's period utility function.
\end{tabular}

of both cost and welfare. The central bank's asset purchases actually result in profits for tax-payers - consistent with the U.S. experience in which the Federal Reserve has made record transfers to Treasury in light of its balance-sheet expansion. Moreover, this policy is preferred from a welfare standpoint. Independent of the transfers to the household resulting from the QE policy, the persistence of the policy speeds-up the recovery from the recession which improves welfare.

In addition to these quantitative factors, there is a political aspect to the comparison of these policies as well. Although not modeled here, equity injections carry a stigma of (i) Directly benefiting Wall Street as opposed to Main Street and (ii) The government taking an ownership stake in a private firm. For example, in Figure (7) the variable 'Share of Large bank Publicly Owned' captures the government's equity stake in the big banks. One could easily argue the welfare rankings between equity injections and QE could reverse if the equity injections are larger or more persistent. However, the political ramifications of equity injections makes such adjustments unrealistic. In totality, QE policies are preferred as they provide sufficient stimulus to offset the crisis without carrying the political costs.

\section{Conclusion}

This paper shows that during the run-up in home prices prior to the Great Recession, off-balance sheet assets became concentrated in the largest commercial banks. When home prices subsequently plunged, these assets shifted to smaller banks. Due to substantial and meaningful differences between small and large commercial banks as cited by the (OCC, 1998-2012), this asset redistribution is not benign.

In order to understand the implications of this heterogeneity and asset redistribution, I develop a DSGE with a two-sided financial friction, both of which are impacted by home prices. The model features heterogeneous banks, who differ between the price they are willing to pay for off-balance sheet assets secured by housing related assets. The moral- 
hazard constraint placed on productive/large banks implies the asset concentration in these banks moves endogenously with home prices - capturing this element from the data. When home prices fall and assets endogenously shift to small banks, an asset price spiral is set off and borrowers are pushed into costly financing. This mechanism amplifies typical downturns into deep recessions.

I then empirically examine the model's testable predictions using a FS-VAR. The data supports the model's predictions that changes in the risk composition of borrowers reduces the concentration of assets in large banks, worsening the supply side financial friction and ultimately further increasing the external finance premium paid by borrowers. Moreover, aggregate economic disturbances serve to change home prices affecting not only the collateral values of risky borrowers, but also the distribution of off-balance sheet assets between banks. Finally, the model's prediction that changes in this distribution affect finance premiums which in turn affects investment and real GDP is confirmed by the FS-VAR.

This empirically verified model is capable of analyzing the relative effectiveness of the unprecedented actions taken by policy makers in the wake of the 2007 financial crisis. Comparing equity injections in "Too Big to Fail" banks and the various "QE" policies of the Fed reveals that a prolonged asset purchase program is preferable to a short-term equity injection using both a (i) Welfare and (ii) Cost to Tax-Payers metric. Moreover, QE policies avoid the political controversies of the government taking an ownership stake in private financial firms and bailing-out Wall Street instead of Main Street. 


\section{References}

Adrian, T., And H. S. Shin (2010): "Financial Intermediaries and Monetary Economics," in Handbook of Monetary Economics, ed. by B. M. Friedman, and M. Woodford, vol. 3 of Handbook of Monetary Economics, chap. 12, pp. 601-650. Elsevier.

(2013): "Procyclical Leverage and and Value at Risk," Staff Reports 338, Federal Reserve Bank of New York.

Anderson, T. (2003): An introduction to multivariate statistical analysis, Wiley series in probability and mathematical statistics. Probability and mathematical statistics. Wiley.

Anderson, T. W., And H. Rubin (1956): "Statistical inference in factor analysis," in Proceedings of the third Berkeley symposium on mathematical statistics and probability, vol. 5, pp. 1-1.

Bernanke, B. S., M. Gertler, and S. Gilchrist (1999): "The financial accelerator in a quantitative business cycle framework," in Handbook of Macroeconomics, ed. by J. B. Taylor, and M. Woodford, vol. 1 of Handbook of Macroeconomics, chap. 21, pp. 1341-1393. Elsevier.

Blanchard, O. J., And D. Quah (1989): "The Dynamic Effects of Aggregate Demand and Supply Disturbances," American Economic Review, 79(4), 655-73.

Bos, J. W., And J. W. Kolari (2013): Optimal size in bankingpp. 77-94. John Wiley \& Sons, Ltd.

Breuer, P. (2000): "Measuring Off-Balance-Sheet Leverage," IMF Working Paper.

Brunnermeier, M. K. (2009): "Deciphering the Liquidity and Credit Crunch 2007-2008," Journal of Economic Perspectives, 23(1), 77-100.

Carlstrom, C. T., and T. S. Fuerst (1997): "Agency Costs, Net Worth, and Business Fluctuations: A Computable General Equilibrium Analysis," American Economic Review, 87(5), 893-910.

Carlstrom, C. T., T. S. Fuerst, A. Ortiz, and M. Paustian (2012): "Estimating contract indexation in a financial accelerator model," Discussion paper.

Christiano, L., R. Motto, and M. Rostagno (2013): "Risk Shocks," NBER Working Papers 18682, National Bureau of Economic Research, Inc. 
Davis, M. A., and J. Heathcote (2005): "Housing And The Business Cycle," International Economic Review, 46(3), 751-784.

Gerali, A., S. Neri, L. Sessa, and F. M. Signoretti (2010): "Credit and Banking in a DSGE Model of the Euro Area," Journal of Money, Credit and Banking, 42(s1), $107-141$.

Gertler, M., and N. Kiyotaki (2010): "Financial Intermediation and Credit Policy in Business Cycle Analysis," in Handbook of Monetary Economics, ed. by B. M. Friedman, and M. Woodford, vol. 3 of Handbook of Monetary Economics, chap. 11, pp. 547-599. Elsevier.

Gorodnichenko, Y. (2005): "Reduced-Rank Identification of Structural Shocks in VARs," Macroeconomics 0512011, EconWPA.

Hafstead, M., ANd J. Smith (2012): "Financial Shocks, Bank Intermediation, and Monetary Policy in a DSGE Model," Unpublished Manucript.

Iacoviello, M. (2005): "House Prices, Borrowing Constraints, and Monetary Policy in the Business Cycle," American Economic Review, 95(3), 739-764.

Iacoviello, M., and S. Neri (2010): "Housing Market Spillovers: Evidence from an Estimated DSGE Model," American Economic Journal: Macroeconomics, 2(2), 125-64.

ICMA (2013): "International Capital Markets Association: What types of asset are used as collateral in the repo market?," http://web.archive.org/web/20080207010024/http: //www. 808multimedia.com/winnt/kernel.htm, Accessed: 2013-03-23.

Kiyotaki, N., and J. Moore (1997): "Credit Cycles," Journal of Political Economy, 105(2), 211-48.

Kydland, F. E., and E. C. Prescott (1982): "Time to Build and Aggregate Fluctuations," Econometrica, 50(6), 1345-70.

OCC (1998-2012): "OCC Bank Derivatives Report," Quarterly report.

Oulton, N., and A. Rincon-Aznar (2009): "Rates of Return and Alternative Measures of Capital Input: 14 Countries and 10 Branches, 1971-2005," Cep discussion papers, Centre for Economic Performance, LSE.

Parkinson, P., M. Gibson, P. Mosser, S. Walter, and A. Latorre (2005): "Concentration and Risk in the OTC Markets for U.S. Dollar Interest Rate Options," Staff report. 
Shen, G. (2011): "News Shocks and the External Finance Premium," The B.E. Journal of Macroeconomics, 11(1), 1-27.

TAYlor, J. B. (1993): "Discretion versus policy rules in practice," Carnegie-Rochester Conference Series on Public Policy, 39(1), 195-214.

Townsend, R. M. (1979): "Optimal contracts and competitive markets with costly state verification," Journal of Economic Theory, 21(2), 265-293.

Wheelock, D. C., And P. W. Wilson (2012): "Do Large Banks Have Lower Costs? New Estimates of Returns to Scale for U.S. Banks," Journal of Money, Credit and Banking, 44(1), 171-199. 


\section{A VAR Data Description}

Table 3: Bank Mergers and Acquisitions

Banks Included in the set of Large Commercial Banks

\begin{tabular}{|c|c|c|c|c|c|c|c|}
\hline 1998:Q2-1999:Q2 & 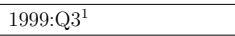 & 1999:Q4² & 2000:Q1-2001:Q3 ${ }^{3}$ & 2001:Q4 - 2002:Q1 ${ }^{4}$ & 2002:Q2 - 2004:Q3 $3^{5}$ & 2004:Q4 - 2009:Q1 ${ }^{6}$ & 2009:Q2 - 2012:Q4 ${ }^{9}$ \\
\hline Wells Fargo Bank NA & Wells Fargo Bank NA & Wells Fargo Bank NA & Wells Fargo Bank NA & Wells Fargo Bank NA & Wells Fargo Bank NA & Wells Fargo Bank NA & Wells Fargo Bank NA \\
\hline First Union NB & First Union NB & First Union NB & First Union NB & First Union NB & Wachovia Bank NA & Wachovia Bank NA & JP Morgan Chase Bank \\
\hline Wachovia Bank NA & Wachovia Bank NA & Wachovia Bank NA & Wachovia Bank NA & Wachovia Bank NA & JP Morgan Chase Bank & JP Morgan Chase Bank ${ }^{8}$ & HSBC Bank USA \\
\hline Morgan Guaranty NY & Morgan Guaranty NY & Morgan Guaranty NY & Morgan Guaranty NY & Bank One Natl. ASSN & HSBC Bank USA & Bank of America NA & \\
\hline First NB of Chicago & First NB of Chicago & First NB of Chicago & Bank One Natl. ASSN & HSBC Bank USA & Bank of America NA & & \\
\hline Bank One NA & Bank One NA & Bank One of NA & HSBC Bank USA & Bank of America NA & & & \\
\hline Republic NB NY & Republic NB NY & HSBC Bank USA & Bank of America NA & & & & \\
\hline
\end{tabular}

Banks Excluded from the set of Commercial Banks

2008:Q4 - 2012:Q4 $4^{7}$

Goldman Sachs

Bank of America NT and SA merges with Nationsbank NA

作

th TR CO of NY merge to form JP Morgan Cla

5 Wachovia acquires First Union National Bank

6 JP Morgan Chase acquires Bank One National ASSN

8 JP Morgan Chase acquired Bear Sterns due to extreme financial distress. Beginning in 2008. Q1 JP Morran Chase experienced increase exposure through repo transactions with Bear Sterns and the ultimate acquisition of Bear Sterns art oll

exposures. This is very difficult to account for since Q-10 SEC filings resort Notional values, not toal credit exposure. Hence, from 2008: Q1-2008:Q4 I use a linear interpolation to assess JP Morgan Chase's total credit exposure.
9 HSBC Bank USA acquires Wachovia Bank NA under financial distress. 


\section{B Equilibrium Model}

In this section I provide the full set of equations which defines the dynamic equilibrium model. All upper case variables are real and lower case variables are nominal - including interest rates. In particular for any nominal interest rate $r_{t}$, the real interest rate is given via the Fisher equation, $R_{t}=\mathbb{E}_{t}\left\{\frac{r_{t}}{\pi_{t+1}}\right\}$.

\section{Household - 5}

$$
\begin{aligned}
\frac{W_{t}^{H}}{C_{t}} & =\frac{\eta^{L^{H}}}{1-L_{t}^{N e w}} \\
\frac{W_{t}^{G, C}}{C_{t}} & =\frac{\eta^{L}}{1-L_{t}^{G, C}} \\
\frac{\eta_{t}^{H}}{H_{t}} & =\frac{P_{t}^{H}}{C_{t}}-\beta \mathbb{E}_{t}\left\{\frac{\left(1-\delta^{H}\right) P_{t+1}^{H}}{C_{t+1}}\right\} \\
\frac{1}{r_{t}^{D}} & =\mathbb{E}_{t}\left\{\Lambda_{t+1}\right\} \\
\Lambda_{t} & =\beta \frac{C_{t-1}}{\pi_{t} C_{t}}
\end{aligned}
$$

\section{Aggregate Goods Production - 7}

$$
\begin{aligned}
Y_{t} & =Z_{t}^{G}\left(K_{t-1}\right)^{\alpha_{G}}\left(L_{t}^{G}\right)^{1-\alpha_{G}} \\
L_{t}^{G} & =\left(L_{t}\right)^{\left(1-\alpha_{E}\right)}\left(L_{t}^{E}\right)^{\alpha_{E}} \\
W_{t} & =\left(1-\alpha_{G}\right)\left(1-\alpha_{E}\right) \frac{Y_{t}}{L_{t}} \\
W_{t}^{E} & =\left(1-\alpha_{G}\right) \alpha_{E} \frac{Y_{t}}{L_{t}^{E}} \\
r_{t}^{K} & =\frac{\alpha_{G} \frac{Y_{t}}{K_{t}}+\left(1-\delta^{K}\right) Q_{t}}{Q_{t-1}} \\
C_{t}^{E} & =\left(1-\alpha_{t}^{N}\right)\left(1-\Gamma_{t-1}\left(\bar{\omega}_{t}\right)\right) R_{t}^{K} K_{t-1} \\
\alpha_{t}^{N} & =\frac{\left(1-F_{t-1}\left(\bar{\omega}_{t}\right)\right) P_{t-1}^{N} R_{t-1}^{D} \bar{N}}{\left(1-\Gamma_{t-1}\left(\bar{\omega}_{t}\right)\right) R_{t}^{K} Q_{t-1} K_{t-1}}
\end{aligned}
$$




\section{Capital Producers - 1}

$$
I_{t}=K_{t}-\left(1-\delta^{K}\right) K_{t-1}
$$

\section{Goods Production: Firm-level Debt Contract - 9}

In this section I provide the equations which determine the debt contract. Moreover, I provide a description of the individual entrepreneur's problem which leads to the aggregate entrepreneur's consumption rule defined in equation (16). In particular, suppose entrepreneuer $j$ has preferences over consumption and housing given by a Cobb-Douglas utility function,

$$
U_{t}(j)=C_{t}(j)^{1-\alpha_{t}^{N}} N_{t}(j)^{\alpha_{t}^{N}}
$$

with

$$
\alpha_{t}^{N}=\frac{\left(1-F_{t-1}\left(\bar{\omega}_{t}\right)\right) P_{t-1}^{N} R_{t-1}^{D} \bar{N}}{\left(1-\Gamma_{t-1}\left(\bar{\omega}_{t}\right)\right) R_{t}^{K} Q_{t-1} K_{t-1}} .
$$

Since entrepreneuer $j$ takes the aggregate default rate $F_{t-1}\left(\bar{\omega}_{t}\right)$ and the aggregate choice of capital, $K_{t}$ as given, this Walrasian demand bundles given these preferences has the wellknown property of constant expenditure shares on consumption and housing.

$$
C_{t}(j)=\left(1-\alpha_{t}^{N}\right)\left(1-\Gamma_{t-1}\left(\bar{\omega}_{t}^{j}\right)\right) R_{t}^{K} K_{t-1}^{j} Q_{t-1}
$$

Aggregating over this equation implies

$$
\begin{aligned}
C_{t} & =\int_{0}^{\infty}\left(1-\alpha_{t}^{N}\right)\left(1-\Gamma_{t-1}\left(\bar{\omega}_{t}^{j}\right)\right) R_{t}^{K} K_{t-1}^{j} Q_{t-1} d j \\
& =\left(1-\alpha_{t}^{N}\right)\left(1-\Gamma_{t-1}\left(\bar{\omega}_{t}\right)\right) R_{t}^{K} K_{t-1} Q_{t-1} \\
& =\left(1-\Gamma_{t-1}\left(\bar{\omega}_{t}\right)\right) R_{t}^{K} K_{t-1} Q_{t-1}-\left(1-F_{t-1}\left(\bar{\omega}_{t}\right)\right) P_{t-1}^{N} R_{t-1}^{D} \bar{N} .
\end{aligned}
$$

The second equality follows from the ex-ante homogeneity among home builders implying they all will choose the same default cut-off, $\bar{\omega}_{t}^{j}$, and the same level of capital expenditures, $K_{t}^{j}$. 


$$
\begin{aligned}
\mathbb{E}_{t}\left\{\Gamma_{t}^{\prime}\left(\bar{\omega}_{t+1}\right) R_{t+1}^{K} Q_{t} K_{t}\right\} & =\lambda_{t}^{E} \mathbb{E}_{t}\left\{\left(\Gamma_{t}^{\prime}\left(\bar{\omega}_{t+1}\right)-\mu^{M} G_{t}^{\prime}\left(\bar{\omega}_{t+1}\right)\right) R_{t+1}^{K} Q_{t} K_{t}\right\} \\
\mathbb{E}_{t}\left\{\left[1-\Gamma_{t}\left(\bar{\omega}_{t+1}\right)\right] R_{t+1}^{K}\right\} & =\lambda_{t}^{E} \mathbb{E}_{t}\left\{R_{t}^{E}-\Gamma_{t}\left(\bar{\omega}_{t+1}\right) R_{t+1}^{K}\right\} \\
& +\lambda_{t}^{E} \mathbb{E}_{t}\left\{\mu^{M} G_{t}\left(\bar{\omega}_{t+1}\right) R_{t+1}^{K}\right\} \\
R_{t}^{E}\left(Q_{t} K_{t}-P_{t}^{N} \bar{N}-W_{t}^{E}\right) & =\mathbb{E}_{t}\left\{\left(\Gamma_{t}\left(\bar{\omega}_{t+1}\right)-\mu^{M} G_{t}\left(\bar{\omega}_{t+1}\right)\right) R_{t+1}^{K} Q_{t} K_{t}\right\} \\
B_{t} & =Q_{t} K_{t}-P_{t}^{N} \bar{N}-W_{t}^{E} \\
z_{t+1} & =\frac{\ln \left(\bar{\omega}_{t+1}\right)+.5\left(\sigma_{t}^{\omega}\right)^{2}}{\sigma_{t}^{\omega}} \\
G_{t}\left(\bar{\omega}_{t+1}\right) & =\Phi^{\mathcal{N}}\left(z_{t+1}-\sigma_{t}^{\omega}\right) \\
\Gamma_{t}\left(\bar{\omega}_{t+1}\right) & =\Phi^{\mathcal{N}}\left(z_{t+1}-\sigma_{t}^{\omega}\right)+\bar{\omega}_{t+1}\left(1-\Phi^{\mathcal{N}}\left(z_{t+1}\right)\right) \\
G_{t}^{\prime}\left(\bar{\omega}_{t+1}\right) & =\left(\frac{1}{\sigma_{t}^{\omega} \sqrt{2 \pi}}\right) e^{-\frac{z_{t+1}^{2}}{2}} \\
\Gamma_{t}^{\prime}\left(\bar{\omega}_{t+1}\right) & =1-\Phi^{\mathcal{N}}\left(z_{t+1}\right)
\end{aligned}
$$

Housing Production: Aggregate Behavior - 2

$$
\begin{aligned}
H_{t}^{N e w} & =Z_{t}^{H}\left(L_{t}^{H}\right)^{\left(1-\alpha_{H}\right)} \\
W_{t}^{H} & =P_{t}^{H}\left(1-\alpha_{H}\right) \frac{H_{t}^{N e w}}{L_{t}^{H}}
\end{aligned}
$$

\section{Productive Bank - 10}

$$
\begin{aligned}
\left\{\left(1-\psi_{t} F_{t}\left(\bar{\omega}_{t+1}\right)\right) B K_{t}^{P}\right\} & =N_{t}^{P} \mathbb{E}_{t}\left\{\frac{Z^{R} P_{t+1}^{H}-\left(1-F_{t}\left(\bar{\omega}_{t+1}\right)\right) P_{t}^{N} R_{t}^{D}}{P_{t}^{N}}\right\} \\
\mathbb{E}_{t}\left\{\Lambda_{t+1} \bar{r}_{t}^{E, P}\right\} & =\mathbb{E}_{t}\left\{\Lambda_{t+1} r_{t}^{D}\right\} \\
\mathbb{E}_{t}\left\{\Lambda_{t+1} \bar{r}_{t}^{E, P}\right\} & =\left(\frac{\theta_{B}-1}{\theta_{B}}\right) \mathbb{E}_{t}\left\{\Lambda_{t+1}\left(1-F_{t}\left(\bar{\omega}_{t+1}\right)\right)\right\} r_{t}^{B, P} \\
& +\mathbb{E}_{t}\left\{\Lambda_{t+1} \pi_{t+1} \frac{\left(1-\mu^{M}\right) \Phi_{t}\left(\bar{\omega}_{t+1}\right)}{B_{t}}\right\}
\end{aligned}
$$




$$
\begin{aligned}
B_{t}^{P} & =\left(\frac{r_{t}^{B, P}}{r_{t}^{B}}\right)^{-\theta_{B}} B_{t} \\
B_{t}^{P} & =D_{t}^{P}+\frac{B K_{t-1}^{P}}{\pi_{t}}-P_{t}^{N} N_{t}^{P} \\
\Pi_{t}^{P} & =\left(1-F_{t-1}\left(\bar{\omega}_{t}\right)\right) \frac{r_{t-1}^{B, P}}{\pi_{t}} B_{t-1}^{P} \\
& +\left(1-\mu^{M}\right) \frac{B_{t-1}^{P}}{B_{t-1}} \Phi_{t}\left(\bar{\omega}_{t+1}\right) \\
& +\left(1-F_{t-1}\left(\bar{\omega}_{t}\right)\right) R_{t-1}^{D} P_{t-1}^{N} N_{t-1}^{P} \\
& +F_{t-1}\left(\bar{\omega}_{t}\right) P_{t}^{H} Z^{R} N_{t-1}^{P}-P_{t}^{N} N_{t}^{P} \\
R_{t-1}^{D} D_{t-1}^{P}+D_{t}^{P}-B_{t}^{P} & \\
D I V_{t}^{P} & =\Pi_{t}^{P} \\
T R A N S_{t}^{P} & =F_{t-1}\left(\bar{\omega}_{t}\right) \psi_{t-1} \frac{B K_{t-1}^{P}}{\pi_{t}} \\
I N V_{t}^{P} & =T^{B, P}-T R A N S_{t}^{P} \\
B K_{t}^{P} & =I N V_{t}^{P}+\left(1-\delta^{B K, P}\right) \frac{B K_{t-1}^{P}}{\pi_{t}}
\end{aligned}
$$

\section{Unproductive Bank - 10}

$$
\begin{aligned}
P_{t}^{N} & =\frac{1}{R_{t}^{D}} \mathbb{E}_{t}\left\{Z^{R} P_{t+1}^{H}-\chi^{R, U} \mu^{R, U} N_{t}^{U}\left(\chi^{R, U}-1\right)\right\} \\
\mathbb{E}_{t}\left\{\Lambda_{t+1} \bar{r}_{t}^{E, U}\right\} & =\mathbb{E}_{t}\left\{\Lambda_{t+1} r_{t}^{D}+\chi^{B, U}\right\} \\
\mathbb{E}_{t}\left\{\Lambda_{t+1} \bar{r}_{t}^{E, U}\right\} & =\left(\frac{\theta_{B}-1}{\theta_{B}}\right) \mathbb{E}_{t}\left\{\Lambda_{t+1}\left(1-F_{t}\left(\bar{\omega}_{t+1}\right)\right)\right\} r_{t}^{B, U} \\
& +\mathbb{E}_{t}\left\{\Lambda_{t+1} \pi_{t+1} \frac{\left(1-\mu^{M}\right) \Phi_{t}\left(\bar{\omega}_{t+1}\right)}{B_{t}}\right\} \\
B_{t}^{U} & =\left(\frac{r_{t}^{B, U}}{r_{t}^{B}}\right)^{-\theta_{B}} B_{t} \\
B_{t}^{U} & =D_{t}^{U}+\frac{B K_{t-1}^{U}}{\pi_{t}}-P_{t}^{N} N_{t}^{P}
\end{aligned}
$$




$$
\begin{aligned}
\Pi_{t}^{U} & =\left(1-F_{t-1}\left(\bar{\omega}_{t}\right)\right) \frac{r_{t-1}^{B, U}}{\pi_{t}} B_{t-1}^{U} \\
& +\left(1-\mu^{M}\right) \frac{B_{t-1}^{U}}{B_{t-1}} \Phi_{t}\left(\bar{\omega}_{t+1}\right) \\
& +\left(1-F_{t-1}\left(\bar{\omega}_{t}\right)\right) R_{t-1}^{D} P_{t-1}^{N} N_{t-1}^{U} \\
& +F_{t-1}\left(\bar{\omega}_{t}\right)\left[P_{t}^{H} Z^{R} N_{t-1}^{U}-\mu^{R, U}\left(N_{t-1}^{U}\right)^{\chi^{R, U}}\right] \\
& -P_{t}^{N} N_{t}^{U}+R_{t-1}^{D} D_{t-1}^{U}+D_{t}^{U}-B_{t}^{U}\left(1+\chi^{B, U}\right) \\
D I V_{t}^{U} & =\Pi_{t}^{U} \\
T R A N S_{t}^{U} & =F_{t-1}\left(\bar{\omega}_{t}\right) \psi_{t-1} \frac{B K_{t-1}^{U}}{\pi_{t}} \\
I N V_{t}^{U} & =T^{B, U}-T R A N S_{t}^{U} \\
B K_{t}^{U} & =I N V_{t}^{U}+\left(1-\delta^{B K, U}\right) \frac{B K_{t-1}^{U}}{\pi_{t}}
\end{aligned}
$$

\section{Aggregate Bank - 10}

$$
\begin{aligned}
\bar{r}_{t}^{E} & =\left[\nu\left(\bar{r}_{t}^{E, U}\right){ }^{1-\theta_{B}}+(1-\nu)\left(\bar{r}_{t}^{E, P}\right){ }^{1-\theta_{B}}\right]^{\frac{1}{1-\theta_{B}}} \\
r_{t}^{E} & =\left(\frac{\theta_{B}}{\theta_{B}-1}\right) \bar{r}_{t}^{E}-\left(\frac{1}{\theta_{B}-1}\right)\left(1-\mu^{M}\right) \frac{\mathbb{E}_{t}\left\{\pi_{t+1} \Phi_{t+1}^{H . B .}\right\}}{B_{t}} \\
R_{t}^{E} & =\frac{r_{t}^{E}}{\pi_{t+1}} \\
R_{t}^{D} & =\frac{r_{t}^{D}}{\pi_{t+1}} \\
r_{t}^{B} & =\left[\nu\left(r_{t}^{B, U}\right) 1-\theta_{B}+(1-\nu)\left(r_{t}^{B, P}\right){ }^{1-\theta_{B}}\right]^{\frac{1}{1-\theta_{B}}} \\
D_{t} & =\nu D_{t}^{U}+(1-\nu) D_{t}^{P} \\
D I V_{t} & =\nu D I V_{t}^{U}+(1-\nu) D I V_{t}^{P} \\
T R A N S_{t} & =\nu T R A N S_{t}^{U}+(1-\nu) T R A N S_{t}^{P} \\
I N V_{t} & =\nu I N V_{t}^{U}+(1-\nu) I N V_{t}^{P} \\
\Phi_{t-1}\left(\bar{\omega}_{t}\right) & =G_{t-1}\left(\bar{\omega}_{t}\right) R_{t}^{K} Q_{t-1} K_{t-1}
\end{aligned}
$$




\section{Market Clearing - 4}

$$
\begin{aligned}
H_{t} & =H_{t}^{N e w}+F_{t-1}\left(\bar{\omega}_{t}\right) Z^{R} \bar{N}+\left(1-\delta^{H}\right) H_{t-1} \\
\bar{N} & =\nu N_{t}^{P}+(1-\nu) N_{t}^{U} \\
Y_{t} & =C_{t}+C_{t}^{E}+I_{t}+I_{t}^{B K}+\mu^{M} \Phi_{t-1}\left(\bar{\omega}_{t}\right)+\nu F_{t-1}\left(\bar{\omega}_{t}\right) \mu^{R, U}\left(N_{t-1}^{U}\right)^{\chi^{R, U}}+\nu \chi^{B, U} B_{t}^{U} \\
G D P_{t} & =C_{t}+I_{t}+P_{t}^{H} H_{t}^{I N V}
\end{aligned}
$$

Monetary Policy - 2

$$
\begin{aligned}
\psi_{t} & =\bar{\psi} \\
\frac{r_{t}^{D}}{\bar{r}^{D}} & =\left(\frac{\pi_{t}}{\bar{\pi}}\right)^{\phi_{\pi}}
\end{aligned}
$$

\section{Exogenous Shocks - 5}

$$
\begin{aligned}
\ln \left(\eta_{t}^{H}\right) & =\left(1-\rho_{\eta^{H}}\right) \bar{\eta}^{H}+\rho_{\eta^{H}} \ln \left(\eta_{t-1}^{H}\right)+\varepsilon_{t}^{\eta^{H}} \\
\ln \left(Z_{t}^{G}\right) & =\left(1-\rho_{Z^{G}}\right) \overline{Z^{G}}+\rho_{Z^{G}} \ln \left(Z_{t-1}^{G}\right)+\varepsilon_{t}^{Z^{G}} \\
\ln \left(\sigma_{t}^{\omega}\right) & =\left(1-\rho_{\sigma^{\omega}}\right) \overline{\sigma^{\omega}}+\rho_{\sigma^{\omega}} \ln \left(\sigma_{t-1}^{\omega}\right)+\varepsilon_{t}^{\sigma^{\omega}} \\
\ln \left(Z_{t}^{H}\right) & =\left(1-\rho_{Z^{H}}\right) \overline{Z^{H}}+\rho_{Z^{H}} \ln \left(Z_{t-1}^{H}\right)+\varepsilon_{t}^{Z^{H}} \\
\ln \left(\psi_{t}^{N, P}\right) & =\left(1-\rho_{\psi^{N, P}}\right) \overline{\psi^{N, P}}+\rho_{\psi^{N, P}} \ln \left(\psi_{t-1}^{N, P}\right)+\varepsilon_{t}^{\psi^{N, P}}
\end{aligned}
$$

